
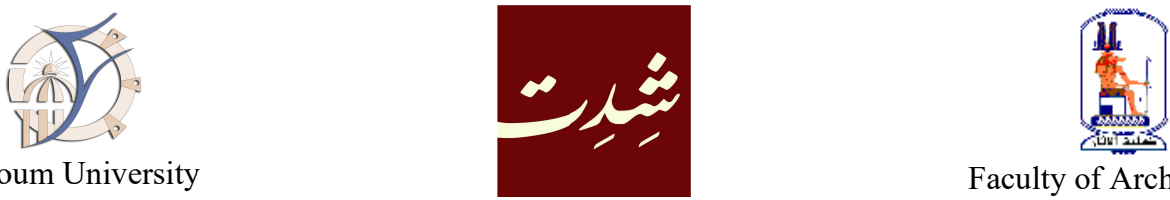

Fayoum University

Faculty of Archaeology

\title{
THE OTTOMAN ARCHITECTURE IN GREECE THEN AND NOW: QUANTITATIVE APPROACH
}

\author{
Ahmed AMEEN \\ Fayoum University, Egypt \\ ahmed.ameen@fayoum.edu.eg
}

\begin{abstract}
Usually, of most studies on the Ottoman architecture in the Balkans are done by comparing between the numbers of buildings then and now. This paper discusses such method with regard to its comparative advantage and maximising its use in understanding Ottoman architecture. With Greece as a case study, the present paper identifies change in the quantity of Ottoman buildings considering the archetypal, functional, chronological, and geographical evidence, in the changing context of the nature of the Ottoman rule over centuries.

The scholar provides new statistics presenting the numbers of Ottoman buildings in Greece over centuries, with special reference to three periods: the second half of the $17^{\text {th }}$ century (time of Evliyâ Çelebi), the late period of the Ottoman rule in Greece (based on Iyverdi's statistics, the Ottoman slanames, and Kamûs-ül Álâm of Şemseddin), and the existing architectural heritage in light of the recent publications and fieldworks' results.

Through statistical methods, this research identifies quantitative change of several types of buildings, proper to each region or in Greece as a whole. It observes the growth or decay of the pace of construction on the basis of three main factors: type of building, period, and region. The most significant results come from the comparison between the numbers of the Ottoman buildings in Greece dating to Evliyâ's time at the end of the $17^{\text {th }}$ century and the last decades of the Ottoman rule.

The statistic table and the two charts with function and region indexes clarify to what extent the change in the number of buildings according to their function and region summarises the different phases of the Ottoman rule and the nature of each phase. The paper shows that the change in the numbers of buildings according to their function summarizes the alteration in nature of the Ottoman policy over the centuries, and the numbers of extant buildings strongly relate to the history and site of the corresponding regions. The paper clarifies that the reasons beyond the demolition of ottoman buildings in Greece include both human and natural factors, and concludes with a recommendation of preserving and reuse of extant ottoman structures.
\end{abstract}

\section{KEYWORDS}

Ottoman architecture, Balkan, Greece, statistic, Mosques, Medrese, Imaret, Zawiya.
الكلمات الدالة

تبلأ معظم الدراسات والبحوث المتعلقة بالعمارة العثمانية في البلقان

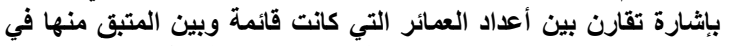

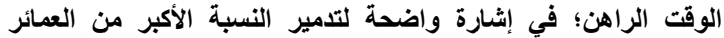

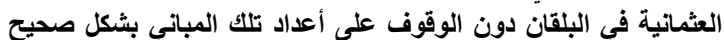

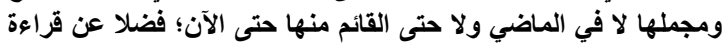

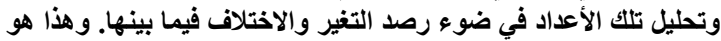

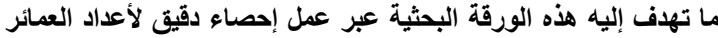

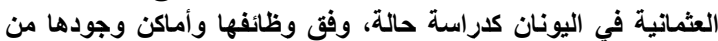

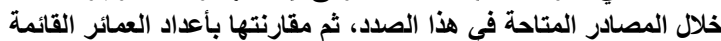

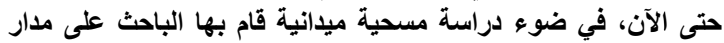

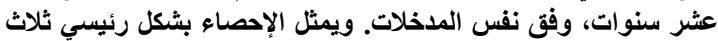

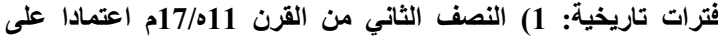

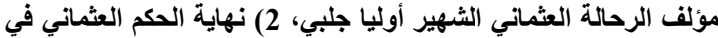

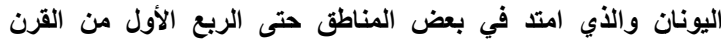

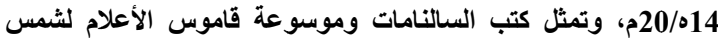

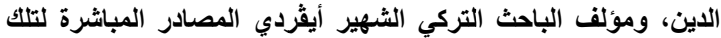
الفترة، 3) الوضع الراهن (حتى 2018) بناء على الاراسة الفئل الميدانية للباحث والمؤلفات الحديثة ذات الصنة الصنة.

وفي هذا السياق تم عمل جدول إحصائي لحصر العمائر العثمانية في

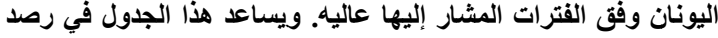

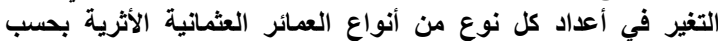

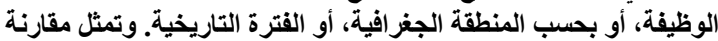

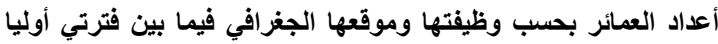

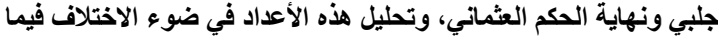

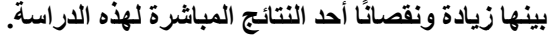

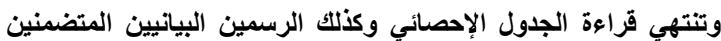

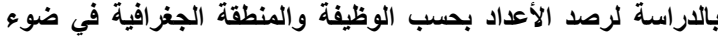

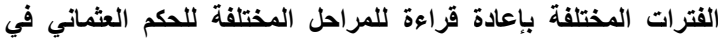
اليونان، وطبيعة كل مرحلة. وتخلص الورقة إلى اللى أن التغير في الأعداد

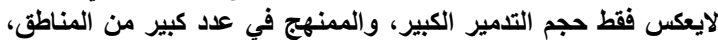

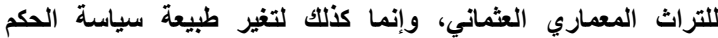

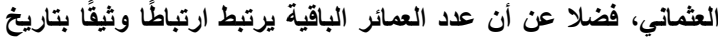

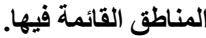

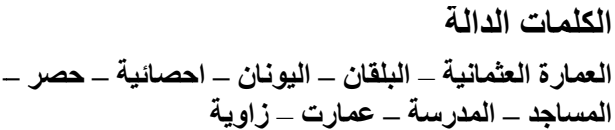




\section{INTRODUCTION}

Thousands of buildings were constructed under the Ottomans patronage in Greece over a period ranging almost from three to five centuries. These architectural edifices gave an Ottoman flavour "Ottomanisation" to the skyline of Greek cities and islands. After the independence of Greek territories, in a desire to eradicating the ottoman impact on cities, besides other factors including wars and earthquakes, a large number of Ottoman architectural heritage was demolished in Greece.

Despite of this, Ottoman buildings in Greece still represent, as a whole, one of the largest well-preserved and varied collection of Ottoman architecture in the Balkans.

Dealing with numbers in studying Ottoman architecture in Greece and all the Balkans is not only a significant issue, but also a tricky approach. In this context, most studies offer general results regarding the numbers of Ottoman historic buildings between then and now. All conclude that the existing Ottoman buildings form no more than $5 \%$ of the original ones. This demolition tends to only be attributed to political reasons or as a result of the local hostility against 'Turkish' objects after the departure of the Ottomans from the Greek territories. They may have been other reasons behind the decreased numbers of Ottoman buildings in Greece, such as wars, earthquakes, new demographic situations ...

Understanding the numbers of Ottoman buildings in Greece then and now (2018) clarifies several aspects regarding the Ottoman construction growth rate in light of building types, time and regional factors. Furthermore, it facilitates identifying the change in numbers of the Ottoman buildings over centuries and its indications.

\section{METHODOLOGY}

This paper provides a new quantitative statistic of Ottoman buildings in Greece. In order to consider a large period of time, three time-frames of Ottoman buildings have been selected, due to the availability of sources:

1) The second half of the 17th century (time of Evliyâ Çelebi).

2) The late period of the Ottoman rule in Greece (based on Iyverdi's statistics, the Ottoman slanames, and Kamûs-ül Â'lâm of Şemseddin).

3) The present state (2018).

These three periods are specifically selected considering the availability of sources that include data, regarding the numbers of ottoman buildings, covering almost all Greece, and classified in quantitative method the types of buildings in each region. Also, the first two time-frames formed the two main historical frames of the ottoman rule in Greece; the utmost point of the ottoman domination of the Greek territories (late $17^{\text {th }} \mathrm{c}$ ), and the end of the ottoman rule of Greece. While the third time-frame identifying the state of ottoman buildings in Greece after the ottoman rule until now (2018) in quantitative method.

The evolution of these numbers is analysed according to the types of buildings and the regions.

\section{SOURCES USED IN THE STATISTICAL MODEL}

Six main categories of sources are used to run the present statistical model:

\section{1) Before Evliyâ Çelebi}

Most territories of present-day Greece were dominated by the Ottomans almost two 
centuries before the journey of Evliyâ, and in some regions up to three centuries prior to that, such as the case of Thrace (1361-1660s). Research on the Ottoman buildings in Greece belonging to this period is a difficult task as it requires to access the early Ottoman archives, among which the most important are TD. (Tahrir Defteri), EV.D. (Evkâf Defterleri), Ev.K.K. (Evkâf Kuyyud-1 Kadîme), VGMA. (Vakıflar Genel Müdürlüğü Arşivi), C. EV. (Cevdet Evkâf), as well as different kinds of registers (Sicil, Defter and Evrâk).

Direct examination of these archives was not available to the researcher. A considerable section of their content has been published in several works ${ }^{1}$, forming the sources of the present paper. Thanks to these, a better understanding of many aspects of early Ottoman rule in the Balkans was made possible. It is worth mentioning that the most recent work Balkanlar'da Osmanlı vakıflarl, vakfiyeler Yunanistan (Ottoman Waqfs in the Balkans: Waqf Deeds in Greece) ${ }^{2}$, by Halit Eren et al. (eds.), IRCICA 2017, is the most useful encyclopaedic work concerning the Vakf works in Greece.

Studying these waqfiyehs is useful to recognize the cultural, religious, commercial, educational, and social contexts of their production period. Moreover, waqfiyehs enable the correction of wrongly identified ottoman buildings in Greece, such as the so-called "A[r]slan Pasha Medrese" in Ioannina (Yanya). ${ }^{3}$ Its waqfiyeh $(1025 \mathrm{H} / 1616)$ clearly determined the building as a zawiya/Khanqah ${ }^{4}$ and not a medrese, describing it as "a nice zawiya with impressive rooms." The same correction is possible for the Veli Pasha Complex in Rethymno (Resmo) ${ }^{5}$ considered to be a "Tekes - Mosque Medrese - Imâret." However, its waqfiyeh did not have any reference to a medrese, but identified it as a tekke following the Qadiriyya order. ${ }^{6}$ For the statistic of ottoman buildings in Greece, there is no doubt that the true identification of the building based on the archives, gives -in terms of building type- an accurate inventory.

Beside the archives, there were also the manuscripts of the Ottoman geographers and cartographers which provided a wealth of information regarding regions in the Balkans, including Greece, in the early centuries of Ottoman rule. The most important

\footnotetext{
${ }^{1}$ Thanks to the studies of Barkan, Gökbilgin, Ayverdi, Eyice, Kiel, Lowry, Balta and others, and the content of the Ottoman archives concerning Ottoman Greece and some other regions in the Balkans, is made available. The works used here the most are: Barkan, "İmaret sitelerinin Kuruluş ve isleyişi." Pp. 239-378; Gökbilgin, Edirne ve Paşa Livâss; Eyice, "Yunanistan'da Türk mimari eserleri."; Ayverdi, Avrupa'da Osmanli Mimari Eserleri, IV.; Kiel, Studies on the Ottoman Architecture of the Balkans, including some important related republished articles; "The Quatrefoil Plan in Ottoman Architecture Reconsidered in Light of the "Fethiye Mosque" of Athens," pp. 109-122; Lowry, Studies in Defterology: Ottoman Society in the Fifteenth and Fifteenth Centuries ; The Nature of the Early Ottoman State; The Shaping of the Ottoman Balkans 1350-1550; Balta, Les vakifs des Serrès et de sa région (XV et XVI s.); Ottoman Studies and Archives in Greece.

${ }^{2}$ Eren et al., Balkanlar'da Osmanlı vaklflarl, vakfiyeler Yunanistan, 5 vols.

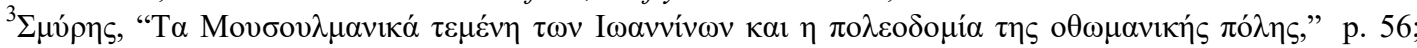
Papadopoulou, “Aslan Pasha Medrese,” p. 163.

${ }^{4}$ VGMA, Defter nr. 623, s. 199, 193, sira 193; Eren et al., Balkanlar'da Osmanll vakuflarl, vol. 4: 123-126, vol. 5: 593-594. This Waqfiyeh specifies the jobs and wages of employees and the financial allocations for resident darwishes in the zawiya, the expenses, types and quantities of food, and the zawiya beneficiaries as students, darwishes, poor and travelers. The Waqfiyeh also referred to the twelve rooms of the zawiya which were inhabited by twelve Sufi darwishes, and identified their duties and allocations as well.

${ }^{5}$ Giapitsoglou, "Veli Pasha Complex. Tekes - Mosque - Medrese - Imâret," p. 442.

${ }^{6}$ VGMA, Defter nr. 734, s. 26-29, sira 10; Eren et al., Balkanlar'da Osmanll vaklflarl, vol. 3: 204-208, vol. $5: 385$.
}

- 95 - DOI: $10.36816 /$ shedet.006.06 
manuscript is Kitab-ı Bahriye (Book of Navigation) by Pîrî Reis ${ }^{7}$ (d.1553), and Menâzirü'l-avâlim (Perspectives of the Worlds) of Âş1k Mehmed ${ }^{8}$ (d. 1598?). The latter provides a detailed description of the city of Thessaloniki (Selânik) in the 1590s.

The work published by Özergin ${ }^{9}$ represents a different set of manuscripts that provided detailed statistics concerning the ottoman buildings in the Balkans. This old inventory gives a thorough count of the ottoman medrese's in Istanbul, Edirne and the Balkan; with reference to their place, names of the founders, and their classification according to the mudrris salary. This classification divided the medrese's into nine categories: $10,15,18,20,25,30,40,50$, and 60 . This interesting work is dated to c. 1660 a few years before the Evliyâ's work. It documents 144 medrese's in the Rumeli in addition to 122 medrese's in Istanbul and 22 in Edirne. It accounts for 44 medrese's in the present-day Greece as follows: Chalkida (Eğriboz) 1, Didymóteichon (Dimetoka) 7, Drama (Dirama) 1, Elassona (Alasonya) 1, Fanari, Andritsaina (Fener) 1, Farsala (Çatalca) 1, Florina (Filorina, Florine) 1, Giannitsa (Yenice-I Vardar) 3, Karytaina (Karitene) 1, Kavala (Kavala) 1, Komotini (Gümülcine) 1, Lamia (İzdin) 2, Larissa (Yenişehir) 4, Methone (Moton, Modon) 1, Nafpaktos (İnebahti) 1, Narda (Arta) 2, Nea Zichni (Zihne) 2, Petras (Balyabadra) 1, Rhodes (Rados, Rodos) 2, Samothraki (Semendire, Semadirek) 1, Serres (Siroz) 2, Sidirokastro (Timurhisar, Demirhisar) 1, Thessaloniki (Selânik) 2, Trikala (Tirhala) 2, Veria (Karaferye) 1, and Ypati or Neopatras (Badracuk) 1.

It is important to note that the abovementioned record did not refer to any medrese in Athens (Atina), Feres (Firecik), Ioannina (Yanya), most parts of the Peloponnese (Mora) and of course Crete (Girid) which has not yet been conquered in 1660 . Comparing the medrese's cited in this record with the numbers of the medrese's mentioned by Evliyâ Çelebi, almost a decade later, one concludes that both inventories are acceptable and very likely to be accurate.

\section{2) Evliyâ Çelebi}

The 10-volumes Seyahatnâmesi by Evliyâ is simply the most useful reference describing the Balkans and other regions during the second half of the $17^{\text {th }}$ century under the Ottomans. Three volumes of which comprise the description of almost all present-day Greek territories and islands. The biggest part of the mainland and Crete are included in the $8^{\text {th }}$ volume, while the islands of Chios (Sakiz), Samothraki (Semadirek), Kos (İstanköy), and Rhodes (Rodos) are in the $9^{\text {th }}$ volume. Volume 5 contains the description of the regions of Florina (Florine), Kastoria (Kesriye), and Servia (Serfiçe). ${ }^{10}$

Complete statistic inventories of Ottoman and non-Ottoman buildings in overall Greece during the last decades of the $17^{\text {th }}$ century could only be done thanks to Evliyâ's work. Any study dedicated to the history and/ or architecture of Greek

\footnotetext{
${ }^{7}$ As far as this paper is concerned, Kitab-1 Bahriye is very useful regarding the Aegean islands. For more about this book, manuscripts, and its content see: Sarıcaoğlu, "KITÂB-ı BAHRIYYE ..., , pp. 72-75.

${ }^{8}$ This valuable work was a reference and inspiration for latter travelers such as Kâtib Çelebi and Evliyâ Çelebi. See: Ak, Aşık Mehmed Menazırü'l-Avalim, Regarding his description of Thessaloniki, see: pp. 983992.

${ }^{9}$ Özergin, "Eski bir rûznâmeye göre İstanbul ve Rumeli Medreseleri,” pp. 271-272.

${ }^{10}$ Evliyâ \#1; Evliyâ \#2; Evliyâ \#3; Evliyâ \#4; Evliyâ \#5; Evliyâ \#6. The statistical data of Evliyâ in the included table are cited from the last three references (Evliyâ \#4, Evliyâ \#5, and Evliyâ \#6). There are many Greek translations for the parts concerning the Greek regions included in Evliyâ's book, among which the most useful are: Evliyâ \#7; Evliyâ \#8; Evliyâ \#9.
} 
regions under the Ottomans has to start with Evliyâ's data, due to the exceptional value of his work. Moreover, his method of describing the regions, cities and buildings was more or less the same way that used, two centuries later, in the Ottoman Salnames.

\section{3) Salnames}

The Salnames or nevsal (Yearbooks) were published during the last epoch of the Ottoman Empire (1847-1918) ${ }^{11}$ and drew a detailed picture of the regions ruled by the Ottomans until then.. Greek cities and islands were no exception. There is a comprehensive description thanks to the following Salnames: Edirne Vilayet Salnâmesi (1287-1319 H/ 1870-1901 A.D.), Cezair Bahr-i Sefid Salnâmesi (12871321 H/ 1870-1903 A.D.), Salnâme-i Vilayet-i Girid (1292-1310 H/ 1875-1892 A.D.), Salnâme-i Vilayet-i Manastır (1292-1314 H/ 1875-1896 A.D.), Selânik Vilayeti Salnâmesi (1287-1325 H/ 1870-1907 A.D.), and Yanya Vilayet Salnâmesi (12881319 H/ 1871-1901 A.D.). These Salnames give very rich information regarding the geographical, geological, political, social and economic details of each city $(\mathrm{Kaza})$ or region (nomos or sancak) in Greece, with exception of regions that had been liberated from the Ottoman rule at the time such as the Peloponnese and Central Greece.

The numbers of Ottoman and non-Ottoman buildings were presented in the Salnames in two different approaches: 1- the numbers come within the description of the city or the region as the case in Yanya Vilayet Salnâmesi 1294: 163-165 and Selânik Vilayeti Salnâmesi 1325: 217, 248, 301, 340, 388, 396, 410, 424.

2- The numbers are cited within the statistics of the buildings types in the Vilayet in the table in which buildings are divided in two: welfare buildings and governmental official ones, as it is the case in Cezair Bahr-i Sefid Salnâmesi 1312:316-317. Moreover both categories of buildings include each building type per its number, such as Salnâme-i Vilayet-i Manastır 1292:102-103, Yanya Vilayet Salnâmesi 1292: 122123 and Cezair Bahr-i Sefid Salnâmesi 1293: 144-147. In these statistics each sancak is mentioned separately with all its cities (kazas), ending with a sum row of the whole sancak; then ended with another sum row for the whole Vilayet. In some cases, the buildings are classified into religious and service buildings, educational buildings, and military buildings as the seen in Crete according to Salnâme-i Vilayet-i Girid 1310: 183-185.

One notices that some later Salnames are written in both Ottoman Turkish and Greek such as the 1303 Cezair Bahr-i Sefid Salnâme (1885-1886). ${ }^{12}$

As mentioned earlier, it is thanks to the Salnames that it is possible to make a statistic of the numbers of the Ottoman buildings in Greece during the late Ottoman period. In this context Salnames are used especially in places that were not addressed by Ayverdi such as the Greek islands. Greek cities and islands that are covered by each

\footnotetext{
${ }^{11}$ For more about the history of the salnames and their types, see: Duman, Osmanll yulliklarl (Salnameler ve Nevsaller).

${ }^{12}$ Bilingual texts in both Turkish and Greek either in the inscriptions of the buildings and the salnames monitor the shifting in the Greek history during the last decades of the Ottoman rule. In some regions, as in Crete after the Pact of Halepa 1878, Greek language was used beside Turkish language in courts, newspapers, inscription... See: Stavrianos, The Balkans since 1453, 470; Türkmen, "Girit Adasini Osmanli İdaresinden Ayirma Çabalari ..., ," pp. 243 - 244; "Bilingual and trilingual inscriptions of the Ottoman buildings in Greece: a search for the history of late ottoman period," Abgadiyat, scientific refereed annual journal, Calligraphy Center - Bibliotheca Alexandrina, 2019 [in press].
} 
Salname are shown in the table of the numbers of Ottoman monuments in Greece (Table 1).

\section{4) Kamûs-ül Â'lâm of Sami Frashëri Şemseddin}

There is a parallel to the Ottoman Salnames, the 6-volumes encyclopaedic work Kamûs-ül Â'lâm (Dictionary of the World) ${ }^{13}$ (1306-1316 H/ 1889-1898 A.D.) of the famous Albanian Writer Sami Frashëri Şemseddin (1850-1904). Published in Ottoman Turkish, it confirms or updates the data included in the Ottoman Salnames regarding the cities and regions of the Balkans under the Ottomans. Thanks to Kamûsül $\hat{A}^{\prime} l a \hat{m}$, it is possible to detect the development, from many aspects, of these cities and regions. Unfortunately, Kamûs-ül Â'lâm does not contain more information on the Ottoman buildings in the Greek cities and regions that were liberated from the Ottoman dominance till its date. Table 1 shows the numbers of Ottoman buildings in Greek cities and islands that are stated in Kamûs-ül Â'lâm.

\section{5) Avrupa'da Osmanli Mimari Eserleri of Ekrem Hakkı Iyverdi}

Avrupa'da Osmanli Mimari Eserleri (Ottoman Architectural Works in Europe), a 4volumes study of Ekrem Hakk1 Ayverdi ${ }^{14}$ is the most distinguished work that deals with the numbers and statistics of the Ottoman buildings in the Balkans. The $19824^{\text {th }}$ volume covers the Ottoman architecture in Bulgaria, Greece, and Albania. The part discussing the Ottoman buildings in Greece, " $V$. KITAP. Yunanistan'da Osmanl Mimari Eserleri" comes in 207 pages: 142 pages of text and 60 pages with 282 figures (including maps, drawings, old photos, author's photos and plans), ending with two tables of the Ottoman buildings found in Greece at the end of the Ottoman dominance.

Iyvredi's book relied mainly on Evliyâ's data. Furthermore, he used the Ottoman archives whenever possible with special reference to the Ev.K.K. (Evkâf Kuyyud-1 Kadîme). He also discussed past and contemporary studies on the topic, and recognized the significance of travelers' drawings and old photographs as an important source to identify ruined and destroyed buildings. Moreover, the fieldwork he implemented, as well as the team he worked with, produced accurate plans and perfect photos included in his book, comprise one of the most characteristic patterns of this study.

As mentioned above, Evliyâ's description of the Ottoman buildings with their names, numbers, and inscriptions formed the core of Iyverdi's study. Thus in several cases, the numbers in both references are the same.

Despite the incomparable value of Iyverdi's work, the data and numbers need to be crosschecked as, in several cases, the cited amounts exceed the actual number of buildings. This is primarily due to the diversity of the names of the same building according to the diverse sources that Iyverdi relied on. As for Athens (Atina), Iyverdi mentioned fourteen mosques within the text, ${ }^{15}$ but cited fifteen mosques in the final statistical table. ${ }^{16}$ Though there were actually only eight Friday mosques (câmi or jammi in Arabic), there were eight minarets: two in the Acropolis Castle and six in the Lower City of Athens. Evliyâ also cited that there were seven small mosques (mescid

${ }_{14}^{13}$ Şemseddin, Kamûs-ül Â'lâm, 6 vols.

${ }_{15}^{14}$ Ayverdi, Avrupa'da Osmanli Mimari Eserleri, IV.

${ }_{16}^{15}$ Ayverdi, Avrupa'da Osmanli, 198-201.

${ }^{16}$ Ayverdi, Avrupa'da Osmanli, 398. 
or masjid in Arabic) in Athens without any reference to their names. However, Iyverdi stated that there was a total of fifteen Friday mosques in Athens.

Furthermore, in some cases there are differences between the numbers stated in the text and those stated in the statistical tables at the end of the Greece section. For instance, the total numbers of mosques (both câmi and mescid) of Chalkida (Ağriboz), Didymóteichon (Dimetoka), Feres (Firecik), Kavala, and Mistras (Mizistire) are not the same in text and statistical tables. These differences caused incorrect amounts in the statistical tables. Moreover the sum included in the statistical tables itself has some mistakes, for instance in the sums of mektep and han buildings. ${ }^{17}$ Furthermore, the book under discussion forwent the Greek islands Rhodes, Kos, Chios, Lesvos (Midilli), and Lemnos (Limni).

The statistic table of the Ottoman buildings in Greece presented here follows, with some adaptations, the form and sequence of the Iyverdi's model. Moreover, our table here sets in parallel the numbers recorded by Evliyâ, the Ottoman Salnames, Kamûs$\ddot{u} l \hat{A}^{\prime} l a ̂ m$, and current recordes.

\section{6) Recent Works}

Many publications and digital studies on the Ottoman buildings in Greece were issued in the past century. While a considerable number of these studies were dedicated to the Ottoman buildings in specific regions ${ }^{18}$ and/ or particular periods,${ }^{19}$ among which few covered Greek territories horizontally, exploring the buildings type throughout Greece, or in a specific regions. As far as this study is concerned, the useful works on the statistics of Ottoman buildings in Greece, even of a specific city or region, are insufficient. On the one hand, the first attempts- such as the articles of Eyice ${ }^{20}$ - were clearly abbreviated and restricted to major cities or main landmarks. On the other hand, the more recent researches dating to the last two decades came more extended and in depth. The most effective, in chronological order, were the studies of Biçakç1 ${ }^{21}$, $\mathrm{Kanetaki}^{22}$, Brouskari ${ }^{23}$-along with its reviewing work of Lowry- ${ }^{24}$, Koutroulas ${ }^{25}$, $\mathrm{Konuk}^{26}$, and Ameen ${ }^{27}$, in addition to some relevant catalogue publications. ${ }^{28}$

The publications of this last category did not only question the architectural history of the Ottoman buildings, but also explored their urban and civilisational significance ${ }^{29}$ as well as their preservation, with special reference to the study of Stefanidou. ${ }^{30}$

17 Ayverdi, Avrupa'da Osmanli, 398-400.

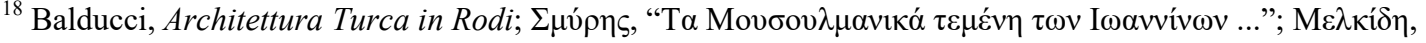

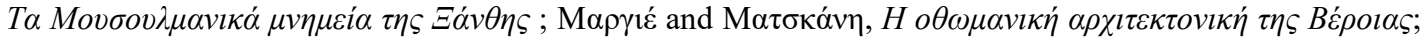

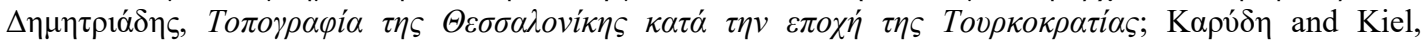

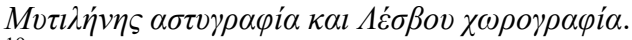

${ }^{19}$ Kiel, "The Oldest Monuments of Ottoman-Turkish Architecture in the Balkans: ... ," pp. 117-144; Lowry, The Shaping of the Ottoman Balkans.

${ }^{20}$ Eyice, "Yunanistan'da Türk mimari eserleri." 1, pp. 157-82 \& 2, pp. 205-30.

${ }^{21}$ Bıçakçı, Yunanistan'da Türk mimari eserleri.

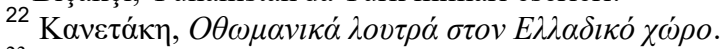

${ }^{23}$ Ottoman Architecture in Greece.

${ }^{24}$ Lowry, Ottoman Architecture in Greece: A Review Article.

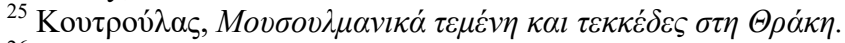

${ }^{26}$ Konuk, Ottoman Architecture in Lesvos, Rhodes, Chios and Kos Islands; Ottoman Architecture in Greece I.

${ }^{27}$ Ameen, Islamic Architecture in Greece: Mosques.

${ }^{28}$ Çam, Yunanistan'Daki Türk Eserleri.

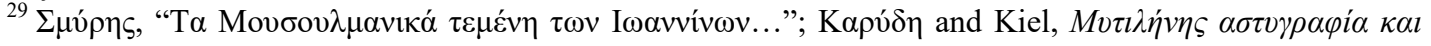

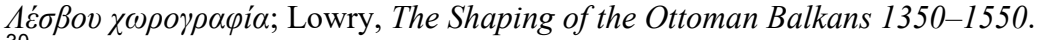

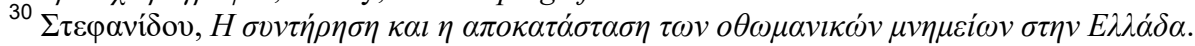


The project "Digital Crete" is an excellent enterprise of digital documentation of the Ottoman monuments in Crete is, and is considered the best reference for the Ottoman buildings in Crete then and now. ${ }^{31}$

In addition to the aforementioned sources, the fieldwork conducted by the author during the years 2006-2016 was essential to record the current state of preservation of the existing Ottoman architectural heritage in Greece.

\section{STATISTIC TABLE OF THE OTTOMAN BUILDINGS IN GREECE THEN \& NOW}

Based on the aforementioned sources, this paper presents a statistic inventory-table of the Ottoman buildings in Greece then and now (Table 1). It follows the Iyverdi's model: the buildings' categories are in the vertical columns and the regions sequence in the horizontal rows. They are in this study thirty eight rows included the regions and islands which Iyverdi forwent. Moreover each region's row is compared with the numbers of the same region as recorded in other sources: Âşık Mehmed, Evliyâ Çelebi, Ottoman Salnames, and Kamûs-ül Â'lâm. Each reference is characterised with a different colour. The grouped rows of the same region end with a row citing the number of the current Ottoman buildings in the region.

There is also a modification in the numbers and order of the columns; starting from the left with a serial column, followed by a new column containing the names of the regions; showing the different names for each region in Ottoman, Modern Turkish, Greek and English with historical clues to the Ottoman period. ${ }^{32}$ Thereafter, a new column comprises the different sources citing the amount of Ottoman buildings for each region. The next column is the Iyverdi's data with the names of the regions, but modified in language and alphabet according to the corresponding source cited in the previous column. The title of this column is adapted to "Place/ Details" instead of "Kaza ve Kariyeler' (city and villages) in Iyverdi's method. Furthermore, the first column of the buildings labeled 'câmi ve mescid' is followed with two new columns: one for Friday mosques 'câmi' and the second for 'mescid'; the number of each category is cited separately, as much as possible, with regard to Iyverdi's text itself and other sources. The column entitled darülkurrâ in Iyverdi's table is merged here with the medrese column, in which the stated numbers of darülkurrâ are very limited. Likewise, the label of the han column is modified to contain the bedestans as well. Moreover, the column entitled 'Kule-Ocak' in the Iyverdi's table is missing here, since no corresponding numbers were cited. There is also a new column at the end labelled Kutubkhane (library), an important classical type of Ottoman building with existing examples.

Thus this table monitors the numbers of Ottoman buildings in Greece with functional, geographical and chronological evidence. Moreover it enables the detection of changes in the numbers of each region according to the same keys, and to compare them from the $17^{\text {th }}$ century, to the early $20^{\text {th }}$ century, against the current known numbers.

\footnotetext{
${ }^{31} \mathrm{http} / /$ digitalcrete.ims.forth.gr/index.php?1=1 [Access Date: April 1, 2016]

${ }^{32}$ Based on the relevant references used in the table for each region, in addition to: Sezen, Osmanli Yer Adlari (Alfabetik Sirayla).
}

The Ottoman architecture in Greece then and now: Quantitative approach 100 - 

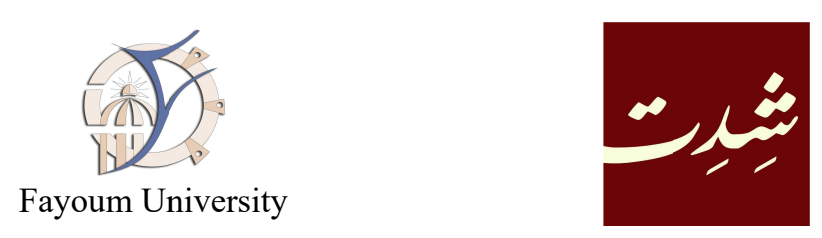

(Table 1) A STATISTIC TABLE OF THE OTTOMAN BUILDINGS IN GREECE THEN AND NOW (5 pages, A. Ameen 2018)

\begin{tabular}{|c|c|c|c|c|c|c|c|c|c|c|c|c|c|c|c|c|c|c|c|c|c|c|c|}
\hline & Place & 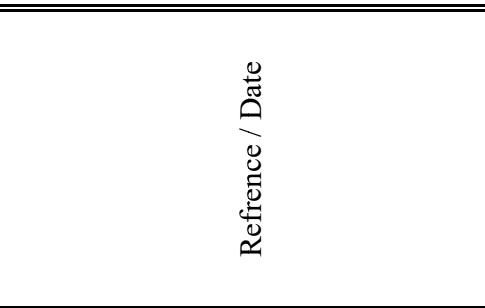 & 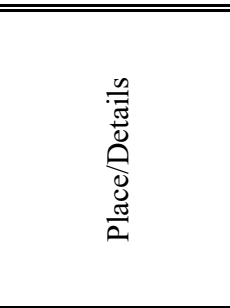 & 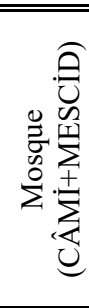 & 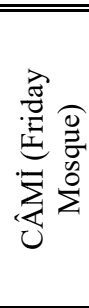 & 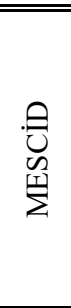 & 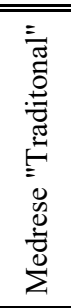 & $\frac{\overline{\mathrm{g}}}{\frac{\mathrm{g}}{\mathrm{g}}}$ & 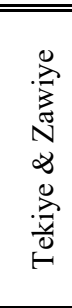 & 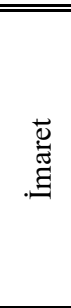 & 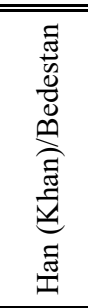 & 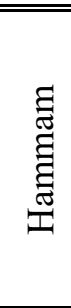 & 㪯 & 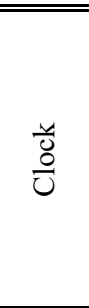 & $\frac{.80}{.0}$ & $\begin{array}{l}\frac{0}{\bar{E}} \\
\tilde{\tilde{E}}\end{array}$ & 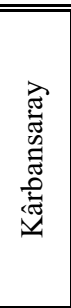 & \begin{tabular}{l} 
: \\
E. \\
\multirow{s}{*}{}
\end{tabular} & $\begin{array}{l}\frac{\vec{U}}{\bar{z}} \\
\frac{\vec{z}}{\bar{Z}}\end{array}$ & $\begin{array}{l}\overline{\overrightarrow{0}} \\
\ddot{0} \\
\tilde{n}\end{array}$ & 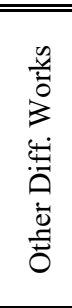 & 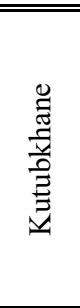 & 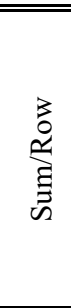 \\
\hline \multirow{4}{*}{1} & \multirow{4}{*}{$\begin{array}{l}\text { Ağriboz (Ĕgriboz jآغر), Eubee, } \\
\text { Boeotia, Chalkida: 1470 Sancak } \\
\text { (Rumeli eyâleti), } 1533 \text { (Kaptanpaşa } \\
\text { eyâleti), 1829 Eyâlet (Greece, } \\
\text { Yunanistan) }\end{array}$} & (Evliyâ 2011a: 236-8) & آغرييوز & 22 & 7 & 15 & $>2$ & $>5$ & $>4$ & & $2 \mathrm{~B}$ & 3 & & & & & & 19 & & & & & 57 \\
\hline & & \multirow{2}{*}{ Iyverdi: 195-7 } & Ağriboz & 20 & 15 & 5 & 6 & 7 & 7 & & 1 & 3 & & & & 2 & & & 1 & & & & 47 \\
\hline & & & Villages & 3 & & & 1 & 1 & 2 & 1 & 2 & & 1 & & & & & & & & 2 & & 10 \\
\hline & & Now & Chalkida & 1 & 1 & 0 & 0 & 0 & 0 & 0 & 0 & 1 & 0 & 0 & 0 & 1 & 0 & 4 & 1 & 0 & 0 & & 8 \\
\hline \multirow{7}{*}{2} & \multirow{7}{*}{$\begin{array}{l}\text { ALASONYA (آلاصونيه), Elasson, } \\
\text { Elassona: } 1889 \text { Kaza (Serfiçe Sancak / } \\
\text { Manastir vilâyeti), 1913: Kaza } \\
\text { (Greece, Yunanistan) }\end{array}$} & (Evliyâ 2011a: 186-7) & آلاصونيه & 10 & 4 & 6 & 1 & 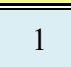 & 1 & 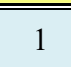 & 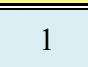 & 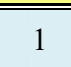 & & & 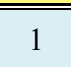 & & & & & & 88 & & 105 \\
\hline & & \multirow{2}{*}{ Shemseddin 1306 (1889). I: 280} & آلاصونيه قصبه & 7 & 4 & 3 & 1 & 1 & & 1 & & & & & & & & & & & & & 10 \\
\hline & & & آلاصونيه قضاء & 15 & --- & -- & 2 & 12 & 1 & 2 & & & & & 16 & & & & & & & & 33 \\
\hline & & Yanya Vilayet Salnâmesi 1294: 163-4 & آلاصونيه & 7 & 4 & 3 & 1 & & & 1 & & & & & & & & 50 & & & & & 59 \\
\hline & & L & Alasonya & 7 & 7 & 0 & 1 & & & 1 & & 1 & 1 & & & & & & & & & & 11 \\
\hline & & 1yverai: $19 /-8$ & Villages & 7 & 6 & 1 & 1 & 1 & 1 & & 1 & & & & & & & & & & & & 11 \\
\hline & & NOW & Elassona & 1 & 1 & 0 & & & & & & & & & & & & & & & 1 & & 2 \\
\hline \multirow{3}{*}{3} & \multirow{3}{*}{ 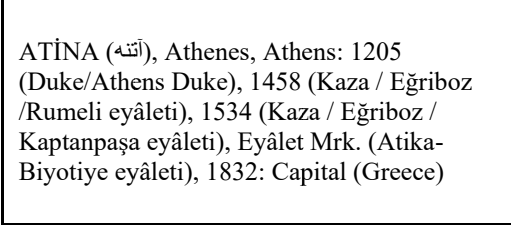 } & (Evliyâ 2011a: 254-5) & آتنه & 11 & 4 & 7 & 1 & 3 & 2 & & 2 & 3 & & & & & & & & & & & 22 \\
\hline & & Iyverdi: 198-201 & Atina & 14 & 14 & $?$ & 2 & 3 & 7 & & 2 & 4 & & & & 1 & & & & & & & 33 \\
\hline & & Now & Athens & 3 & 3 & 0 & 1 & & & & & 1 & & & & & & 1 & & & & & 6 \\
\hline \multirow{4}{*}{4} & \multirow{4}{*}{ 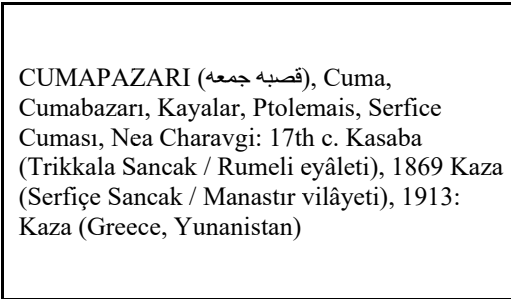 } & (Evliyâ 201 1a: 214) & قصبه جمعه & 7 & 2 & 5 & 1 & 2 & 3 & & 2 & 1 & & & & & & & & & 20 & & 36 \\
\hline & & Iyverdi: 201-2 & Cumapazarı & 5 & 5 & 0 & 1 & 2 & & & 2 & 1 & & & & & & & & & & & 11 \\
\hline & & Iyverdi: 202-3 & Villages & 52 & 49 & 3 & & & & & & 1 & & & 1 & & & & & & & & 54 \\
\hline & & NOW & Nea Charavgi & & & & & & & & & & & & & & & & & & & & 0 \\
\hline \multirow{6}{*}{5} & \multirow{6}{*}{$\begin{array}{l}\text { Dedeağaç (جأ (َ) oد), } \\
\text { Alexandroupoli, Alexandroupolis: } \\
1865 \text { Kaza (Dimetoka / Edirne } \\
\text { vilâyeti), Sancak (Edirne), } 1913 \\
\text { Sancak (Bulgaria, Bulgaristan), } \\
\text { 1919 Sancak (Greece, } \\
\text { Yunanistan) }\end{array}$} & \multirow{2}{*}{ Shemseddin 1308 (1891). III: 2123-4 } & دده آغاج قصبه & 2 & 1 & 1 & 1 & 3 & & & & 2 & & & & & & & & & & & 8 \\
\hline & & & دده آغاج سنجق & 105 & 103 & 2 & 2 & 111 & 18 & & 22 & 6 & & & & & & 249 & & & & & 513 \\
\hline & & Edirne Vilayet Salnâmesi 1319: 1070 & دده آغاج & 2 & 2 & -- & 1 & 4 & & & & & & & & & & 12 & & & & & 19 \\
\hline & & \multirow{2}{*}{ Iyverdi: $203-4$} & Dedeağaç & 5 & 4 & 1 & & 1 & & & & & & & & & & & & & & & 6 \\
\hline & & & Villages & 6 & 5 & 1 & 1 & & & & & 1 & & & & & & & & & & & 8 \\
\hline & & NOW & Alexandroupoli & 1 & 1 & & & & & & & & & & & & & & & & & & 1 \\
\hline \multirow{6}{*}{6} & \multirow{6}{*}{ 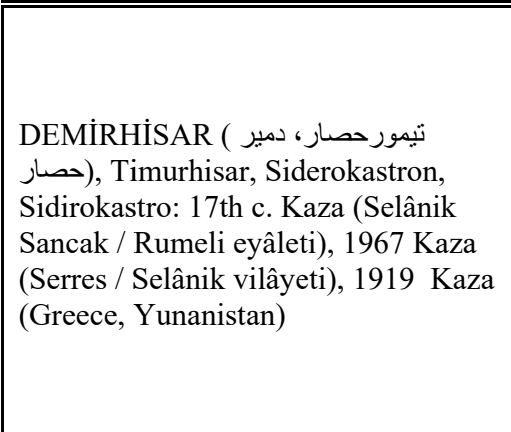 } & (Evliyâ 2011a: 137) & تيمور حصار & --- & --- & --- & --- & --- & --- & --- & --- & --- & & & & & & & & & & & 0 \\
\hline & & Shemseddin 1891. III: $1724-5$ & تيمور حصاء & 35 & 25 & 10 & 1 & 23 & & & 35 & 2 & & & 4 & & & & & & & & 100 \\
\hline & & Selanik Vilayeti Salnâmesi 1325: 388 & تيمور حصار & 6 & 6 & --- & 4 & 3 & & & 31 & 1 & & & & & & & & & & & 45 \\
\hline & & \multirow{2}{*}{ Iyverdi: 204-6 } & Demirhisar & 24 & 22 & 2 & 2 & & 6 & & & 1 & & & & & & & & & & & 33 \\
\hline & & & Villages & 27 & 27 & 0 & & & 2 & 1 & & 1 & & & & & & & & & & & 31 \\
\hline & & NOW & Sidirokastro & --- & --- & --. & --. & --. & --. & --- & --. & --- & & & & & & & & & & & 0 \\
\hline
\end{tabular}


SHEDET (6) 2019

\begin{tabular}{|c|c|c|c|c|c|c|c|c|c|c|c|c|c|c|c|c|c|c|c|c|c|c|c|}
\hline & Place & 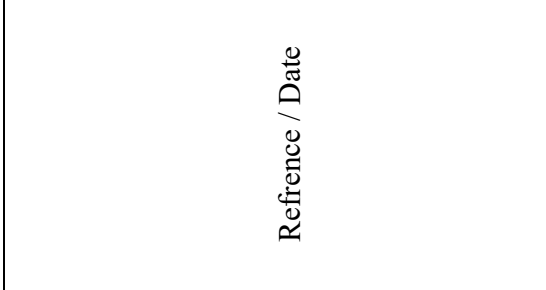 & 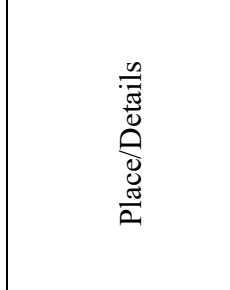 & 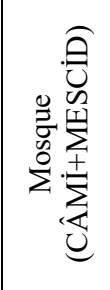 & 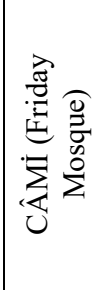 & 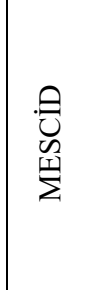 & 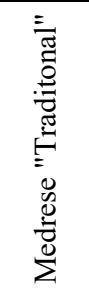 & $\frac{\frac{5}{5}}{\frac{5}{2}}$ & 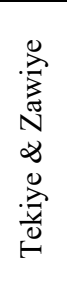 & 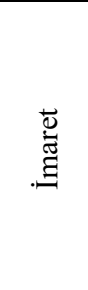 & 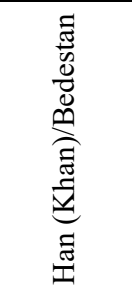 & $\begin{array}{l}\text { E్ } \\
\text { 䔍 } \\
\text { 吾 }\end{array}$ & 童 & $\frac{\ddot{0}}{0}$ & 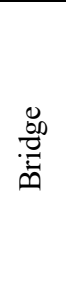 & $\frac{0}{8}$ & 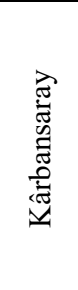 & 惫 & 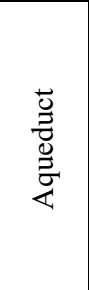 & 言 & 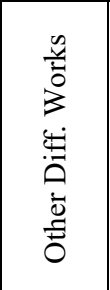 & 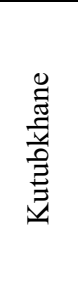 & 言 \\
\hline \multirow{6}{*}{7} & \multirow{6}{*}{ 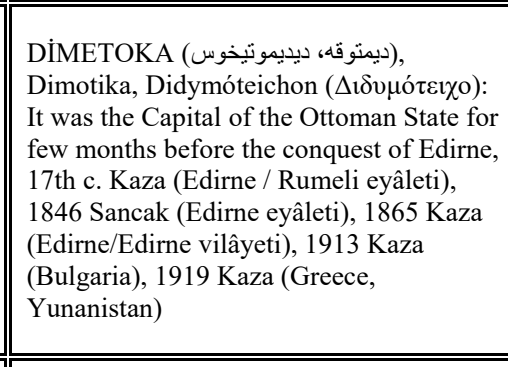 } & (Evliyâ 2011a: 71) & ديمترة & 12 & 1 & 11 & 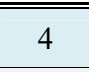 & 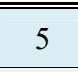 & 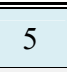 & 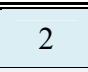 & 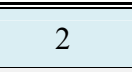 & 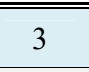 & & & & & 2 & & & & & & $\overline{355}$ \\
\hline & & \multirow{2}{*}{ Shemseddin 1891. III: $2215-6$} & ديمتوقه قصبه & 10 & 7 & 3 & 1 & 2 & 3 & & & & & & & 1 & & & & & & & 17 \\
\hline & & & ديمتوقه قضاء & 23 & 11 & 12 & 2 & 18 & $>3$ & & & & & & & 1 & & & & & & & 47 \\
\hline & & Edirne Vilayet Salnâmesi 1319: 997 & ديمتوقه & 10 & 7 & 3 & 2 & 36 & 3 & & 6 & & & & & & & & & & & & 57 \\
\hline & & Iyverdi: $206-216$ & $\begin{array}{l}\text { Dimetoka } \\
\text { Villawas }\end{array}$ & 27 & 16 & 11 & 6 & 16 & 2 & 3 & 1 & 3 & 1 & & & & 2 & & & & & & 61 \\
\hline & & NOW & \begin{tabular}{|c} 
Villages \\
Didymóteicho
\end{tabular} & $\frac{104}{2}$ & $\frac{97}{2}$ & \begin{tabular}{|l}
7 \\
\end{tabular} & 2 & 2 & $\frac{9}{10}$ & 4 & & 2 & $\frac{1}{1}$ & & & 2 & & 1 & & & 2 & & 122 \\
\hline \multirow{6}{*}{8} & \multirow{6}{*}{ 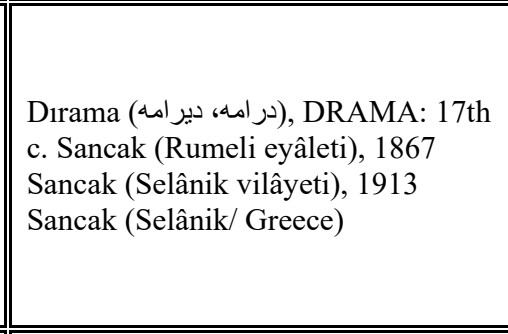 } & $\begin{array}{l}\text { (Evliyà 2011a: 119) } \\
\end{array}$ & Sدرامه & $\overline{16}$ & 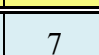 & 9 & & & 3 & & & 2 & & & & 1 & & & & & & & 18 \\
\hline & & Shemseddin. III: $2126-7$ & درامه & & 3 & ... & 2 & $>3$ & & & 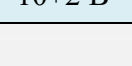 & & & & & & & & & & & 1 & 40 \\
\hline & & Selanik Vilayeti Salnâmesi 1325: 410 & هرامه & 16 & 8 & 8 & 3 & 4 & 3 & & 30 & 2 & & & & & & 46 & & & many & & 104 \\
\hline & & & Drama & 27 & 21 & 6 & 7 & 14 & 6 & 1 & & 1 & & & & & & & 1 & & 1 & & 58 \\
\hline & & Iyverdi: $216-221$ & Villages & 138 & 131 & 7 & 3 & 3 & 4 & & 2 & 2 & & & & & & & & & & & 152 \\
\hline & & Now & Drama & 3 & 2 & 1 & & & & & & & & & & & & 1 & & & many & & 4 \\
\hline \multirow{3}{*}{9} & \multirow{3}{*}{ 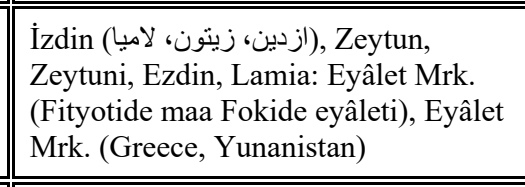 } & (Evliyâ 201 la: $216-7$ ) & ازدين & 7 & 4 & 3 & 3 & 6 & $?$ & 1 & 2 & 2 & & & 5 & & & & & & & & 26 \\
\hline & & Iyverdi: 221 & İzdin & 3 & 3 & 0 & & & & & & 2 & & & 1 & & & & & & & & 6 \\
\hline & & NOW & Lamia & 0 & 0 & 0 & & & & & & 1 & & & & 1 & & 3 & & & & & 5 \\
\hline \multirow{5}{*}{10} & \multirow{5}{*}{ 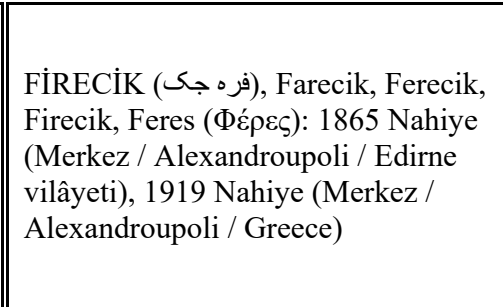 } & (Evliyâ 201 1a: 74) & 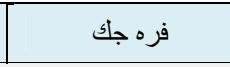 & 7 & 3 & 4 & 2 & 5 & 2 & & 5 & 1 & & & & & & & & & & & 22 \\
\hline & & \multirow{3}{*}{$\begin{array}{l}\text { Shemseddin } 1314 \text { (1896). V: } 3402 \\
\text { Iyverdi: } 221-4\end{array}$} & فره جك & 3 & 2 & 1 & & & 4 & & & & & & & & & & & & & & 7 \\
\hline & & & Firecik & 10 & 6 & 4 & 3 & & 10 & & 1 & 1 & 1 & & & & & & & & & & 26 \\
\hline & & & Villages & 31 & 30 & 1 & & & & & & & & & & & & & & & & & 31 \\
\hline & & NOW & Firecik & & & & & & & & & 1 & 1 & & & & & & & & 1 & & 3 \\
\hline \multirow{4}{*}{11} & \multirow{4}{*}{ 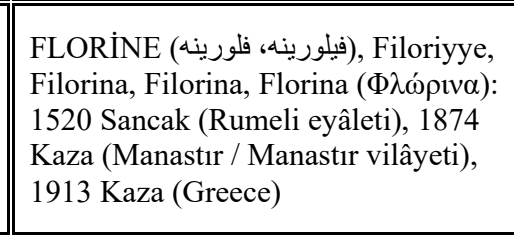 } & \begin{tabular}{l|l} 
(Evliyà 2010: 799) \\
\end{tabular} & |فلورينه & $\begin{array}{lll}17 \\
\end{array}$ & & & 3 & 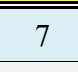 & 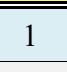 & & 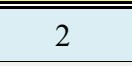 & $\overline{22}$ & & & & & & & & & & 1 & 16 \\
\hline & & Shemseddin V: 3434 & فلورينه & 7 & 7 & -- & 3 & 5 & & & 19 & 1 & & & & & & & & & & & 35 \\
\hline & & Iyverdi: 224 & Florine & 20 & & & 3 & 8 & 1 & 1 & 2 & 2 & & & & & & & & & & & 17 \\
\hline & & NOW & Florina & 1 & 1 & & & & & & & 1 & & & & & & & & & some & & 2 \\
\hline \multirow{15}{*}{12} & \multirow{15}{*}{ 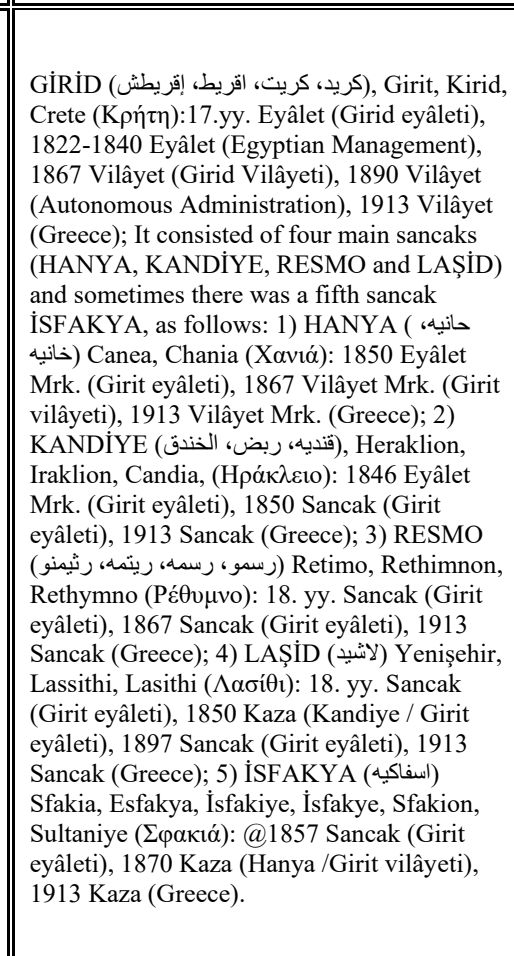 } & \multirow{4}{*}{ 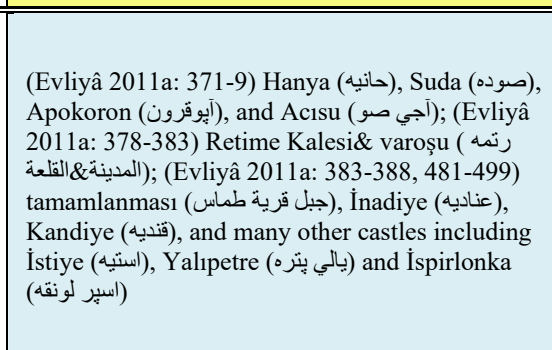 } & $\begin{array}{l}\text { Hanya \& } \\
\text { Regions }\end{array}$ & 16 & 8 & 8 & & 1 & & & $8+1 \mathrm{~B}$ & $\overline{8}$ & & & 1 & & & $>2$ & & & & & 37 \\
\hline & & & $\begin{array}{l}\text { Retime \& } \\
\text { Regions }\end{array}$ & 17 & 7 & 10 & 2 & 3 & 3 & 3 & 3 & 2 & & & & & & 10 & & & & & 43 \\
\hline & & & $\begin{array}{c}\text { Kandiye \& } \\
\text { Regions } \\
\end{array}$ & 142 & 26 & 116 & 12 & 14 & 19 & & 24 & 16 & & & & & & 73 & & & many & & 300 \\
\hline & & & Total Crete & 175 & 41 & 134 & 14 & 18 & 22 & 3 & 27 & 26 & 0 & 0 & 1 & 0 & 0 & 83 & & & & & 369 \\
\hline & & \multirow{4}{*}{ 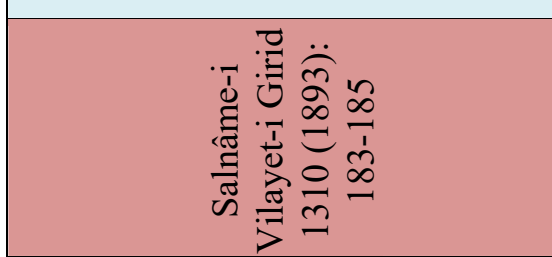 } & Chania & 30 & 24 & 6 & 1 & 60 & 14 & & 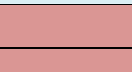 & & & 2 & & - & - & 9 & & 2 & & & 118 \\
\hline & & & $\begin{array}{l}\frac{\text { Kandiye }}{\text { Resmo }} \\
\end{array}$ & 40 & 26 & \begin{tabular}{|l|}
34 \\
14
\end{tabular} & $\frac{2}{5}$ & $\frac{11}{44}$ & $\frac{10}{7}$ & & & & & 1 & & & & 21 & & $\frac{4}{0}$ & & & 118 \\
\hline & & & Lashid & 47 & 35 & 12 & 1 & 33 & 0 & & & & & 0 & & & & 10 & & 0 & & & 91 \\
\hline & & & Total Crete & 218 & 152 & 66 & 9 & 228 & 37 & & & & & 6 & & & & 66 & & 6 & & & 570 \\
\hline & & Shemseddin V: 3856 & كريا & 175 & 175 & -.- & --- & $\ldots$ & --- & -- & 19 & --- & & & & & & & & & & & 194 \\
\hline & & \multirow[t]{6}{*}{ Iyverdal: $224-233$} & Girid & 75 & 59 & 16 & 9 & 35 & 11 & 5 & 27 & 28 & 1 & & & 2 & & 1 & & 1 & 89 & & 284 \\
\hline & & & Chania & 9 & 8 & 1 & 1 & 1 & 2 & 1 & 1 & 4 & 4 & & & 1 & & 12 & & & 50 & & 86 \\
\hline & & & Kandiye & 10 & 9 & 1 & & & 3 & & & 3 & 3 & & & 2 & & 15 & & 1 & 16 & & 53 \\
\hline & & & Resmo & 8 & 8 & & & 1 & 2 & 1 & & 8 & 3 & & & 3 & & 8 & & & 15 & 1 & 50 \\
\hline & & & $\begin{array}{l}\text { Lashid } \\
\end{array}$ & 2 & 2 & & & & & & & & & & & 1 & & 3 & & & 2 & & 8 \\
\hline & & & Total Crete & 29 & 27 & 2 & 1 & 2 & 7 & 2 & 1 & 15 & 10 & 0 & 0 & 7 & 0 & 38 & 0 & 1 & 83 & 1 & 197 \\
\hline
\end{tabular}




\begin{tabular}{|c|c|c|c|c|c|c|c|c|c|c|c|c|c|c|c|c|c|c|c|c|c|c|c|}
\hline & Place & 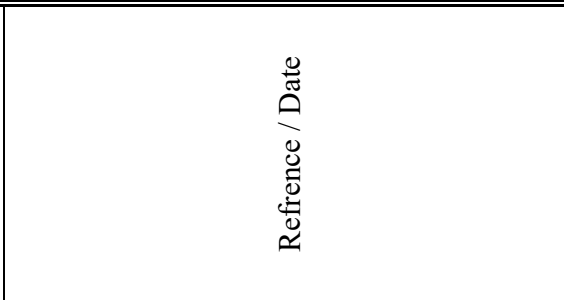 & 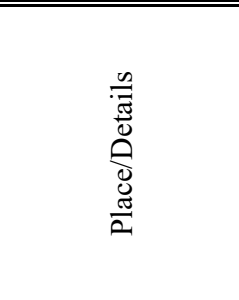 & 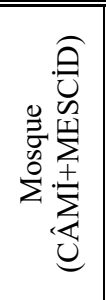 & 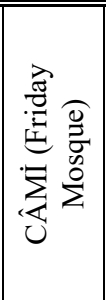 & $\begin{array}{l}\text { : } \\
\text { ñ } \\
\text { 致 }\end{array}$ & 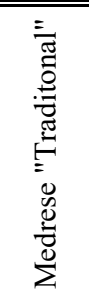 & $\frac{\bar{v}}{\frac{\vec{s}}{2}}$ & 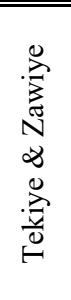 & 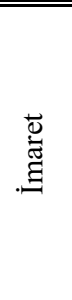 & 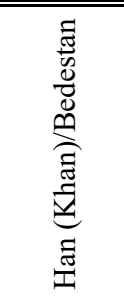 & 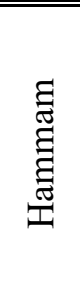 & 兽 & $\frac{\breve{c}}{\dot{0}}$ & 总 & $\begin{array}{l}\frac{0}{\bar{E}} \\
\text { J }\end{array}$ & 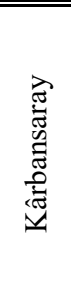 & 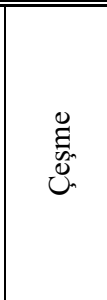 & 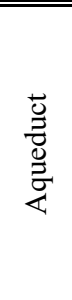 & $\begin{array}{l}\overline{\overline{0}} \\
\overline{0} \\
\bar{n}\end{array}$ & 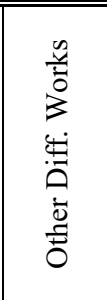 & 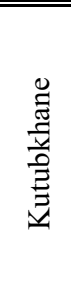 & 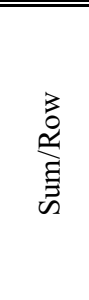 \\
\hline \multirow{6}{*}{13} & \multirow{6}{*}{ 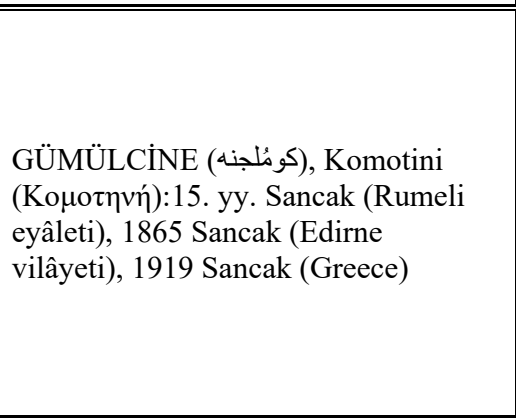 } & (Evliyâ 2011a: 84-85) & كومُلجنه قصبه & 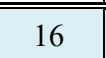 & 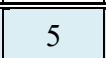 & 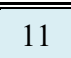 & 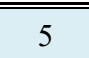 & 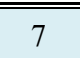 & 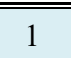 & 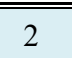 & $\begin{array}{l}17 \\
\end{array}$ & 22 & & & & & & many & & & & & 50 \\
\hline & & Shemseddin V: 3925 & كومُلجنه قصبه & 25 & 10 & 15 & 4 & 10 & 2 & & & & 4 & & & 1 & & 125 & & & many & 1 & 172 \\
\hline & & Salname 1309 (1892): 227-8 & كومُلجنه قصبه & 25 & 10 & 15 & 9 & 9 & 3 & 1 & & 1 & 20 & & 12 & & & 156 & & & many & & 236 \\
\hline & & Salname 1309 (1892): 227-8 & كومُلجنه قضاء & 152 & 87 & 65 & 9 & 115 & 8 & 1 & & 1 & 20 & & 1 & & & 226 & & & many & & 533 \\
\hline & & Iyverdi: 235-243 & $\begin{array}{l}\text { Gümülcine \& } \\
\text { Regions }\end{array}$ & 166 & 126 & 40 & 8 & 10 & 10 & 2 & 17 & 2 & 1 & 1 & & & & & & & & & 217 \\
\hline & & NOW & Komotini/city & 19 & 19 & & 1 & & 1 & 1 & 1 & 1 & 1 & 1 & & & & 2 & & & 2 & 1 & 31 \\
\hline \multirow{5}{*}{14} & \multirow{5}{*}{ 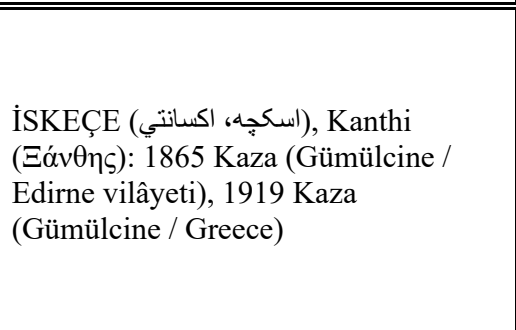 } & $\begin{array}{l}\text { (Evliyâ 2011a: 111) } \\
\end{array}$ & اسكجه & 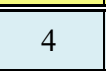 & 1 & 3 & $\bar{~} 1$ & & 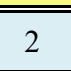 & & 2 & 1 & & & & & & & & & & & 10 \\
\hline & & \multirow{2}{*}{$\begin{array}{l}\text { Salname 1309 (1892): 234; } 1317 \text { (1899): 448; } \\
1319 \text { (1901): 1059-1060; }\end{array}$} & اسكجه قصبه & 7 & 5 & 2 & 1 & 4 & 3 & & & & & 1 & & & & & & & 15 & & 31 \\
\hline & & & اسكجه قضاء & 108 & 49 & 59 & 2 & 130 & . & & 63 & 5 & & . & & & & 213 & & & & & 521 \\
\hline & & Iyverdi: 243-248 & İskeçe \& Regions & 171 & 149 & 22 & 2 & 1 & 1 & & & & 1 & 1 & 2 & & & & & & & & 179 \\
\hline & & NOW & Xanthi & 7 & 7 & --- & & & 2 & & & & & 1 & 2 & & & & & & & & 12 \\
\hline \multirow{2}{*}{15} & \multirow{2}{*}{ 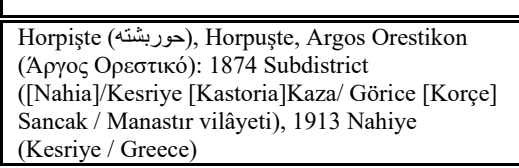 } & 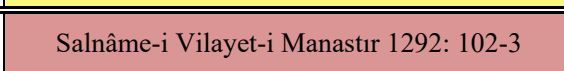 & حوربشته ناحيه & $\overline{5}$ & $\overline{5}$ & $\begin{array}{c}-- \\
-\end{array}$ & 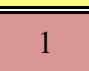 & $\overline{1}$ & & & 3 & 1 & & & & & & & & & & & 11 \\
\hline & & Iyverdi: 248 & Horpiş̧te & 13 & 11 & 2 & & & & & & & & & & & & & & & 1 & & 14 \\
\hline \multirow{7}{*}{16} & \multirow{7}{*}{$\begin{array}{l}\text { KARAFERYE (قرى هريه), Karaferya, } \\
\text { Veria (Bépoou): 1867 Kaza (Selânik } \\
\text { Sancak / Selânik vilâyeti) }\end{array}$} & \begin{tabular}{|l} 
DT 935 (1528)/(M.K. \&E.G, TDV İA 24: 391- \\
394)
\end{tabular} & قره فريه & 8 & 1 & 7 & 2 & & 3 & & $1 \mathrm{~B}$ & 3 & & & & & & & & & & & 17 \\
\hline & & (Evliyâ 2011a: 179) & قره فريه & 25 & 16 & 9 & 3 & 10 & 5 & 3 & $15+1 \mathrm{~B}$ & 5 & & & 1 & & & & & & & & 68 \\
\hline & & Shemseddin V: 3640 & قره فريه & 19 & & & 2 & 6 & 4 & & & & & & & & & & & & 8 & & 20 \\
\hline & & Selânik Vilâyeti Salnâmesi 1325: 248 & 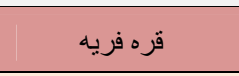 & 19 & & & 3 & & 4 & & & & & & & & & & & & 8 & & 15 \\
\hline & & \multirow{2}{*}{ Iyverdi: $248-251$} & Karaferye & 31 & 19 & 12 & $5+3$ & 11 & 5 & 6 & 15 & & & & 1 & & & & & & & & 77 \\
\hline & & & Villages & 2 & 2 & 0 & & & & & & & & & & & & & & & & & 2 \\
\hline & & NOW & Veria & 6 & 6 & 0 & & & & & & 1 & & & 1 & & & & & & 3 & & 11 \\
\hline \multirow{2}{*}{17} & \multirow{2}{*}{ 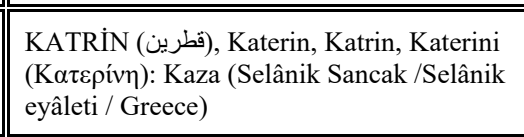 } & Iyverdi: 251 & $\begin{array}{c}\text { Katrin } \\
\end{array}$ & 1 & 1 & 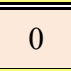 & & 3 & 1 & & & & & & & & & & & & & & 5 \\
\hline & & NOW & Katrini & & & & & 1 & & & & & & & & & & & & & & & 1 \\
\hline \multirow{7}{*}{18} & \multirow{7}{*}{ 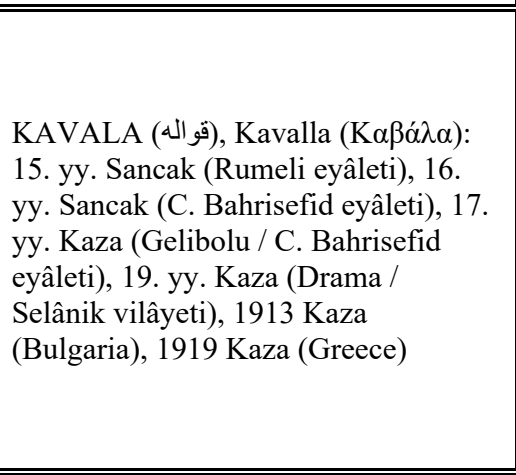 } & \multirow{2}{*}{ (Evliyâ 2011a: 179) } & قو اله / قلعة & 25 & 3 & 2 & & & & & & & & & & & & & & & & & 5 \\
\hline & & & قو اله قصبه & 6 & 6 & 0 & 1 & 1 & 1 & 1 & $3+1 \mathrm{~B}$ & 1 & & & & & & & & 1 & & & 16 \\
\hline & & Shemseddin V: 3704 & قو اله قصبه & 6 & 6 & & 5 & 9 & 3 & 1 & & & & & & & & & & & & 1 & 25 \\
\hline & & Selânik Vilâyeti Salnâmesi 1325: 424 & قو قاله & 10 & 8 & 2 & 6 & 8 & & 1 & 16 & & & & & & & & & & many & 1 & 42 \\
\hline & & \multirow{2}{*}{ Iyverdi: 251-255 } & Kavala & 22 & 18 & 4 & 7 & 2 & 1 & 2 & 1 & 1 & & & & & & & 1 & & 1 & & 38 \\
\hline & & & Villages & 32 & 28 & 4 & 1 & 1 & 4 & & 4 & 4 & & & & & & & & & & & 46 \\
\hline & & NOW & Kavala & 4 & 4 & 0 & 2 & 1 & & 1 & & & & & & 1 & & 1 & 1 & & & & 11 \\
\hline \multirow{6}{*}{19} & \multirow{6}{*}{ 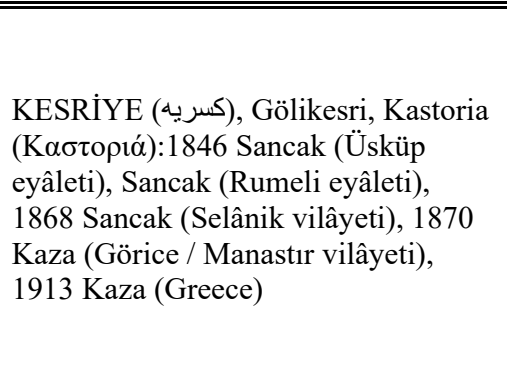 } & (Evliyâ 2010: 801-805) & كسريه & 3 & 3 & 0 & & 10 & & & & 2 & & & & & & & & & many & & 15 \\
\hline & & Salnâme-i Vilayet-i Manastır 1292: 102-3 & كسريه - ايه & 6 & 6 & & 1 & 5 & 7 & & 4 & 1 & & & & & & & & & many & & 24 \\
\hline & & Shemseddin V: 3860 & كسريه & 7 & 7 & --- & 2 & 3 & & & 3 & 2 & & 1 & & & & & & & & & 18 \\
\hline & & \multirow{2}{*}{ Iyverdi: $255-7$} & Kesriye & 14 & 14 & 0 & 1 & 1 & 3 & & 1 & 1 & 1 & & & & & & & & 1 & & 23 \\
\hline & & & Villages & 26 & 26 & 0 & & 1 & 1 & & 1 & 2 & & & & & & & & & & & 31 \\
\hline & & NOW & Kastoria & 2 & 2 & 0 & 1 & & & & & & & & & 1 & & & & & 2 & & 6 \\
\hline
\end{tabular}




\begin{tabular}{|c|c|c|c|c|c|c|c|c|c|c|c|c|c|c|c|c|c|c|c|c|c|c|c|}
\hline & Place & 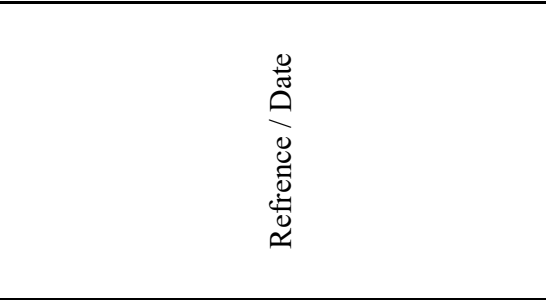 & 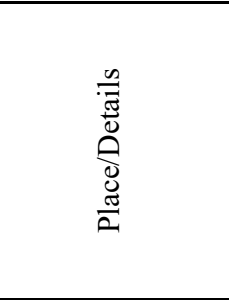 & 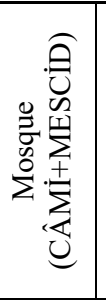 & 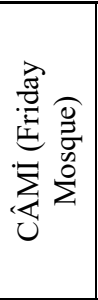 & 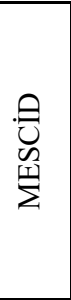 & 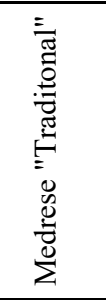 & 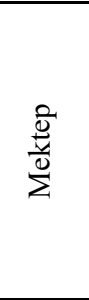 & 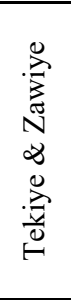 & 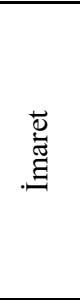 & 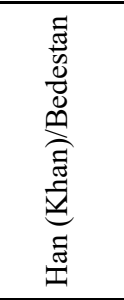 & 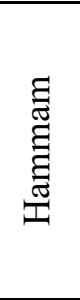 & 兽 & $\begin{array}{l}\frac{\breve{0}}{U} \\
\frac{8}{U}\end{array}$ & 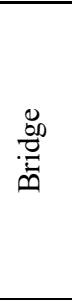 & 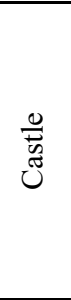 & 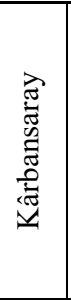 & 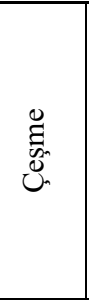 & 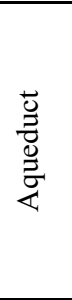 & $\begin{array}{l}\overline{\overline{0}} \\
\overline{0} \\
\text { ñ }\end{array}$ & 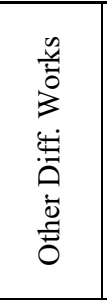 & 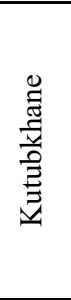 & 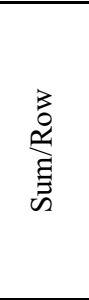 \\
\hline \multirow{3}{*}{20} & \multirow{3}{*}{ 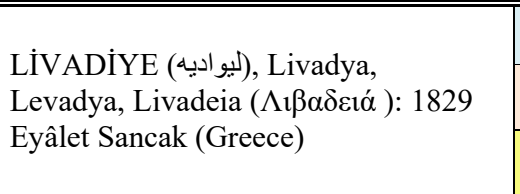 } & (Evliyâ 2011a: 228) & 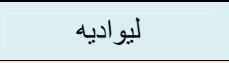 & 7 & 5 & 2 & 2 & 3 & 3 & & & & & & & & & & & & & & 15 \\
\hline & & Iyverdi: $257-8$ & LIVADIYE & 8 & 6 & 2 & 2 & 3 & 4 & & & & & & & & & & & & & & 17 \\
\hline & & NOW & Livadeia & 1 & 1 & 0 & & & & & & & & & 1 & & & & & & & & 2 \\
\hline \multirow{3}{*}{21} & \multirow{3}{*}{ 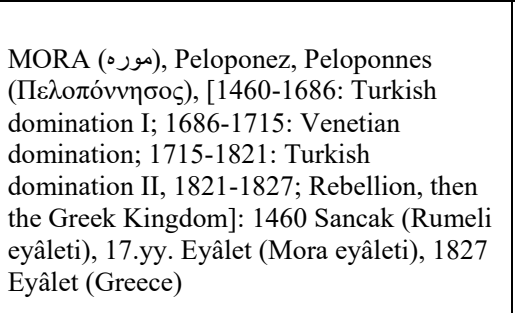 } & \multirow{3}{*}{ 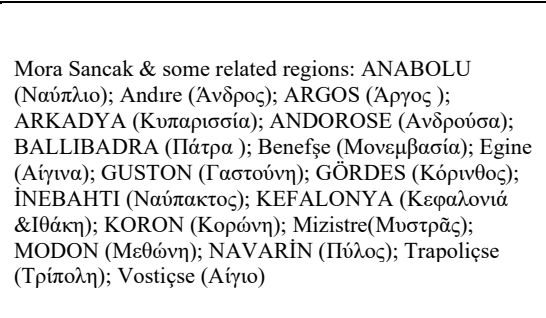 } & $\begin{array}{c}\text { Evliyâ \# 5: 270- } \\
\quad 366\end{array}$ & 128 & 63 & 65 & 26 & 39 & 33 & 2 & 24 & 24 & 0 & 0 & 3 & 6 & 3 & 2 & 0 & 0 & 6 & 0 & 296 \\
\hline & & & $\begin{array}{c}\text { Iyverdi: } 258- \\
269 \\
\end{array}$ & 129 & 80 & 35 & 19 & 35 & 26 & 1 & 15 & 23 & 2 & 0 & 1 & 7 & 3 & 2 & 0 & 0 & 1 & 0 & 250 \\
\hline & & & Peloponnes & 12 & 12 & 0 & 1 & 0 & 0 & 0 & 0 & 6 & 0 & 0 & 0 & 7 & 0 & 7 & 1 & 0 & 2 & 0 & 36 \\
\hline \multirow{8}{*}{22} & \multirow{8}{*}{ 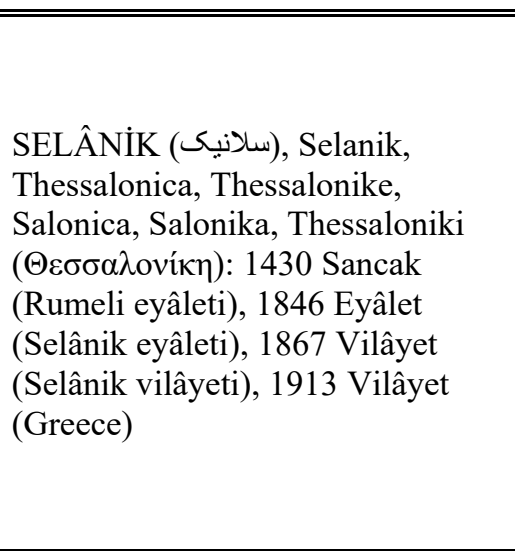 } & Âşık Mehmed 1590s v.3: 983-992 & سلانيك & 28 & 11 & 17 & & & & & $?+1 \mathrm{~B}$ & $\begin{array}{c}7 \text { or } \\
8\end{array}$ & & & & & & & & & & & 36 \\
\hline & & (Evliyâ 201 1a: 149-167) & سلانيك & 182 & 32 & 150 & many & many & $>3$ & 16 & 16 & 11 & & & & 1 & $>3$ & 64 & & $>3$ & many & & 299 \\
\hline & & Shemseddin 1311, IV: 2591 & سلانيك & 56 & 56 & $?$ & 7 & many & 23 & & 15 & & & & & & & & & & & 1 & 102 \\
\hline & & Selanik Vilayeti Salnâmesi 1322: 346-350 & سلانيك & 67 & 35 & 32 & 9 & many & 16 & & & & & & & 2 & & & & & many & & 94 \\
\hline & & Selanik Saln. 1324: 222 & سلانبك & & 35 & $?$ & 9 & 9 & 19 & 3 & & & & & & & & & & & many & & 75 \\
\hline & & \multirow{2}{*}{ Iyverdi: 269-291 } & Selânik & 126 & 78 & 48 & 17 & 16 & 40 & 8 & 4 & 8 & 6 & & & 3 & 1 & 1 & & & 11 & & 241 \\
\hline & & & Selânik/Villages & 132 & 129 & 3 & 4 & 3 & 8 & & 3 & 5 & & & & & 1 & 2 & & & 1 & & 159 \\
\hline & & NOW & Thessaloniki & 4 & $\underline{5}$ & 0 & & & & 1 & $1 \mathrm{~B}$ & 5 & 1 & & & 2 & & 4 & & & many & & 19 \\
\hline \multirow{6}{*}{23} & \multirow{6}{*}{$\begin{array}{l}\text { SİROZ (سيروز), Serez, Siruz, } \\
\text { Sirez, Serres ( } \Sigma \dot{\varepsilon} \rho \rho \varepsilon \zeta): 1867 \\
\text { Sancak (Selânik vilâyeti), } 1913 \\
\text { Sancak (Selânik / Greece) }\end{array}$} & (Evliyâ 2011a: 126-9) & 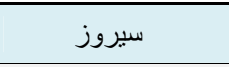 & 91 & 12 & 79 & $>2$ & 27 & $>3$ & $>1$ & $17+1 \mathrm{~B}$ & 5 & & & 3 & & & 710 & & 70 & many & & 930 \\
\hline & & Shemseddin 1311, IV: 2755 & 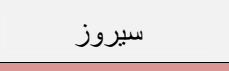 & $>29$ & 29 & $?$ & 11 & 12 & 15 & 3 & 23 & & & & & & & & & & many & 1 & 94 \\
\hline & & Selanik Vilayeti Salnâmesi 1325: 340 & سبروز & $>36$ & 36 & $?$ & 11 & 14 & 15 & & 44 & & & & & & & & & & many & 1 & 121 \\
\hline & & \multirow{2}{*}{ Iyverdi: 291-302 } & Siroz & 101 & 79 & 22 & 8 & 41 & 41 & 6 & 2 & 6 & 2 & & 2 & & 1 & & 2 & 1 & 4 & & 217 \\
\hline & & & Siroz/Villages & 105 & 102 & 3 & 2 & 4 & 1 & & 2 & 2 & & & 1 & & 1 & & & & & & 118 \\
\hline & & NOW & Serres & 3 & 3 & 0 & & & & & $1 \mathrm{~B}$ & 1 & & & & & & 1 & & & & & 6 \\
\hline \multirow{6}{*}{24} & \multirow{6}{*}{ 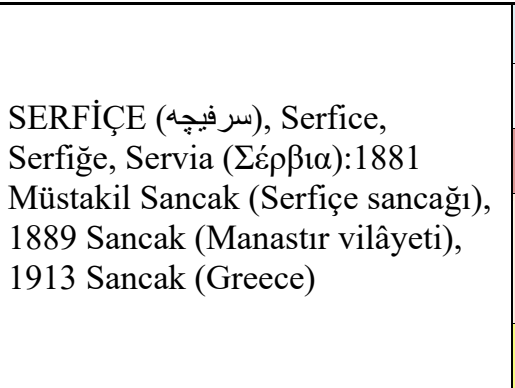 } & (Evliyâ 2010: 812) & سرفيجه & 12 & 6 & 6 & 0 & 2 & 1 & 0 & 1 & 1 & & & & & & & & & & & 17 \\
\hline & & Shemseddin 1311, IV: 2552 & سرفيجه & $>4$ & 4 & $?$ & 1 & 1 & 1 & --- & 9 & 2 & & & & & & & & & some & & 18 \\
\hline & & Salnâme-i Vilayet-i Manastrr 1292: 102-3 & 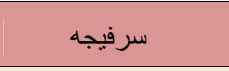 & 6 & 6 & 0 & 1 & 2 & 1 & --- & 10 & 2 & & & & & & & & & & & 22 \\
\hline & & \multirow{2}{*}{ Iyverdi: $302-3$} & Serfiçe & 8 & 8 & 0 & & 6 & 3 & 1 & 1 & 1 & & & & & & & & & & & 20 \\
\hline & & & Villages & 2 & 2 & 0 & & 1 & & & & & & & & & & & & & & & 3 \\
\hline & & NOW & Servia & & & & & & & & & & & & & 1 & & & & & 1 & & 2 \\
\hline \multirow{2}{*}{25} & \multirow{2}{*}{ 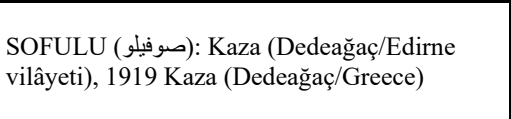 } & \multirow{2}{*}{ Iyverdi: 303} & $\begin{array}{l}\text { Sofulu } \\
\end{array}$ & 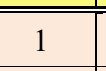 & 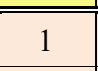 & 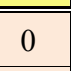 & & & & & & $\overline{1}$ & & & 2 & & & & & & & & 4 \\
\hline & & & Villages & 4 & 4 & 0 & & & & & & & & & & & & & & & & & 4 \\
\hline \multirow{5}{*}{26} & \multirow{5}{*}{ 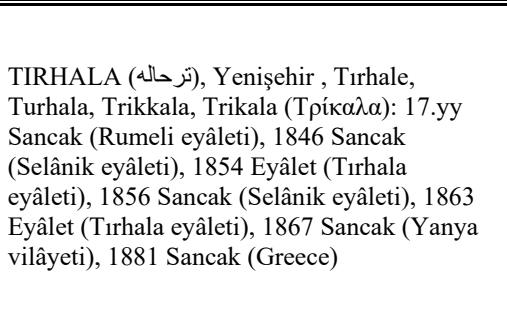 } & (Evliyâ 2011a: 200-203) & ترحاله & 16 & 8 & 8 & 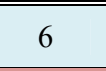 & 9 & 8 & 3 & 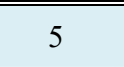 & 13 & & & 5 & & & 1001 & & & many & & 1066 \\
\hline & & Yanya Vilayet Salnâmesi 1294: 123-4 & ترحاله & 15 & & & & 149 & 18 & --- & 25 & 1 & & & 9 & & & 25 & & & & & 227 \\
\hline & & \multirow{2}{*}{ Iyverdi: $303-6$} & Tirhala & 33 & 23 & 10 & 5 & 10 & 10 & 3 & 1 & 4 & 1 & & 7 & & & & & & & & 74 \\
\hline & & & Villages & 3 & 2 & 1 & & & & & & & & & & & & & & & & & 3 \\
\hline & & NOW & Trikala & 1 & 1 & 0 & & & & & & & 1 & 1 & & 1 & & & & & 2 & & 6 \\
\hline
\end{tabular}




\begin{tabular}{|c|c|c|c|c|c|c|c|c|c|c|c|c|c|c|c|c|c|c|c|c|c|c|c|}
\hline & Place & 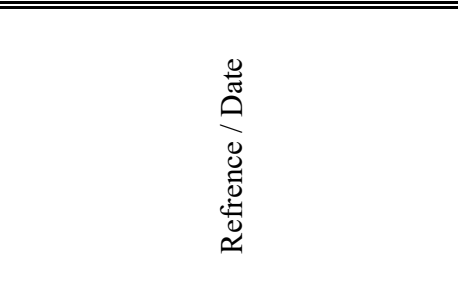 & 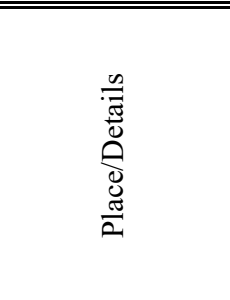 & 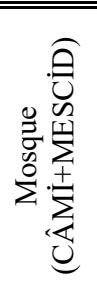 & 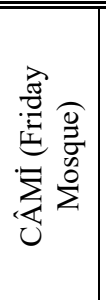 & 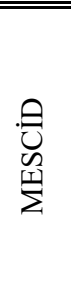 & 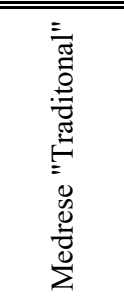 & 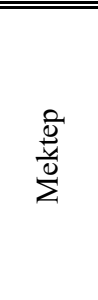 & 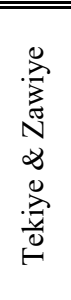 & 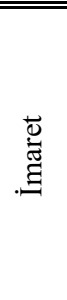 & 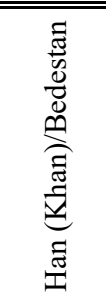 & 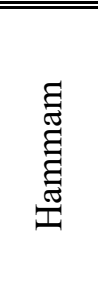 & 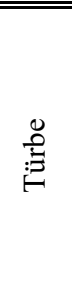 & $\begin{array}{l}\frac{\ddot{0}}{0} \\
\frac{0}{U}\end{array}$ & 总 & 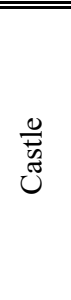 & 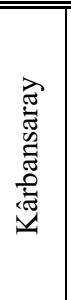 & 莺 & 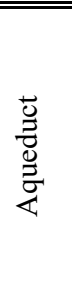 & 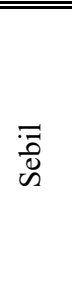 & 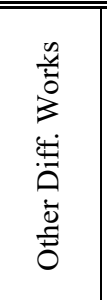 & 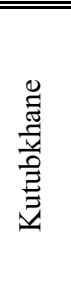 & 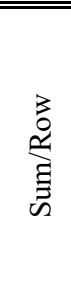 \\
\hline \multirow{6}{*}{27} & \multirow{6}{*}{ 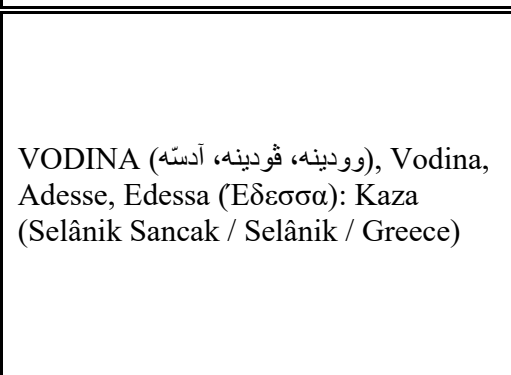 } & (Evliyâ 2011a: 174-5) & و ودينا & 20 & 9 & 11 & 1 & 4 & 2 & 1 & 10 & 1 & & & & & & & & & & & 39 \\
\hline & & Shemseddin 1316 (1898), VI: 4699 & وودينه & $>12$ & 12 & --- & 2 & 4 & 7 & & 14 & & & & & & & & & & many & & 39 \\
\hline & & $\begin{array}{l}\text { Selanik Vilayeti Salnâmesi 1325: } 217 \\
\end{array}$ & 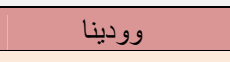 & 14 & 9 & 5 & 1 & 2 & 7 & & & 1 & & & & & & & & & & & 25 \\
\hline & & \multirow{2}{*}{ Iyverdi: 306-9 } & Vodine & 20 & 19 & 1 & 1 & 6 & 5 & 1 & 10 & & & & & & & & & & 1 & & 44 \\
\hline & & & Villages & 52 & 49 & 3 & 2 & 2 & 1 & & 1 & & & & & & & & & & & & 58 \\
\hline & & NOW & Edessa & 1 & 1 & 0 & & & & & & & & & & & & & & & & & 1 \\
\hline \multirow{6}{*}{28} & \multirow{6}{*}{ 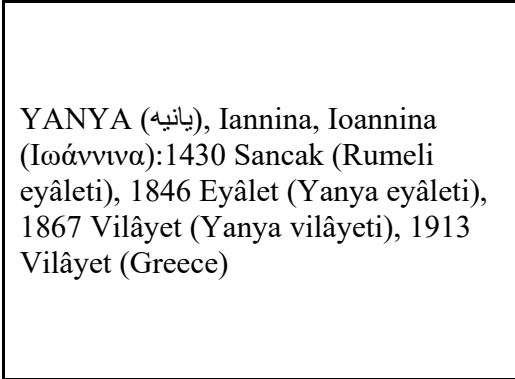 } & (Evliyâ 2011a: 627-9) & يانيه & 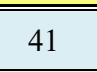 & 22 & 19 & $6+3+2$ & 11 & 7 & & 3 & 2 & & & & & & 2 & & & & & 77 \\
\hline & & Shemseddin 1316 (1898), VI: 4789 & يانيه & $>30$ & 30 & --- & many & many & 3 & & many & many & & & & 1 & & & & & & 1 & 35 \\
\hline & & Yanya Vilayet Salnâmesi 1294: 123-4 & يانيه / قصبه & $>19$ & 19 & --- & 7 & 14 & 7 & & 62 & 5 & & & & 1 & & 2 & & & & & 117 \\
\hline & & & Yanya & 39 & 36 & 3 & 6 & 16 & 15 & 2 & 3 & 1 & & 1 & & 1 & & & & & & & 84 \\
\hline & & lyverdı: 309-313 & Villages & 11 & 9 & 2 & 7 & 9 & 3 & & 2 & 1 & & & & 1 & & & & & & & 34 \\
\hline & & NOW & Iaonnina & 4 & 4 & 0 & 1 & & 1 & 1 & 1 & 2 & 1 & 1 & & 2 & & & & & 3 & 1 & 18 \\
\hline \multirow{4}{*}{29} & \multirow{4}{*}{$\begin{array}{l}\text { NARDA (نارد), Narde, Narta, Arta } \\
\text { ('Apta): 14. yy. Sancak (Rumeli } \\
\text { eyâleti), 1849 Sancak (Yanya eyâleti), } \\
\text { 1867 Kaza (Preveze /Yanya eyâleti), } \\
1881 \text { Kaza (Greece) }\end{array}$} & (Evliyâ 2011a: 619-620) & نارده & 15 & 6 & 9 & 3 & 5 & 3 & & 1 & $?$ & & 1 & & 1 & & & & & & & 29 \\
\hline & & Yanya Vilayet Salnâmesi 1294: 123-4 & نارده/قضاء & $>8$ & 8 & $-\ldots$ & 2 & 41 & 1 & & 15 & 2 & & & 25 & & & 110 & & & & & 204 \\
\hline & & Iyverdi: $313-6$ & Narda & 16 & 13 & 3 & 10 & 13 & 6 & 4 & 8 & 3 & & 1 & 1 & 1 & & & & & & & 63 \\
\hline & & NOW & Arta & 1 & 1 & 0 & & & & & & & & & 1 & & & & & & & & 2 \\
\hline \multirow{4}{*}{30} & \multirow{4}{*}{ 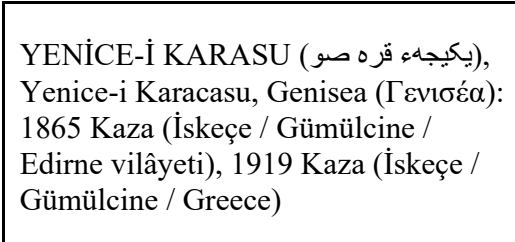 } & (Evliyâ 201 la: 109-110) & قره صو يكيجه سي & 5 & 2 & 3 & 1 & 3 & 2 & 1 & 11 & 1 & & & 1 & & 1 & & & & & & 26 \\
\hline & & \multirow{2}{*}{ Iyverdi: $316-9$} & Yenice Karasu & 9 & 9 & 0 & 1 & & 3 & 1 & & 1 & & & & & 1 & & & & & & 16 \\
\hline & & & Villages & 74 & 71 & 3 & 2 & & & & & & & & & & & & & & & & 76 \\
\hline & & NOW & Genisea & 2 & 2 & 0 & & & 1 & & & & & & & & & & & & & & 3 \\
\hline \multirow{6}{*}{31} & \multirow{6}{*}{ 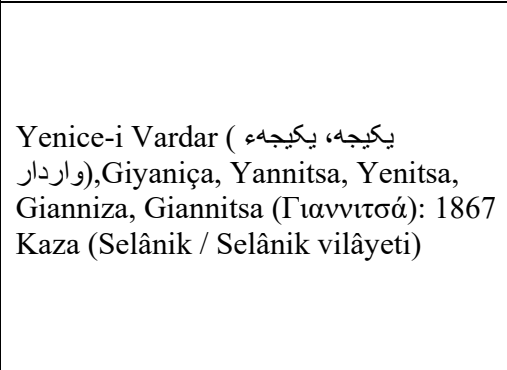 } & (Evliyâ 2011a: 167-9) & يكيجه & 17 & (25 & 12 & 1 & 7 & 3 & 3 & $9+1 \mathrm{~B}$ & 3 & & & & & 1 & 22 & & & & & 67 \\
\hline & & Shemseddin 1316 (1898), VI: 4803 & يكيجه & $>10$ & 10 & --- & 2 & 6 & & 2 & 35 & 3 & & & & & & & & & many & & 58 \\
\hline & & Selanik Vilayeti Salnâmesi 1325: 301 & يكيجه & 19 & 10 & 9 & 2 & 6 & 5 & & 15 & 3 & 11 & 1 & & & 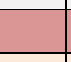 & & 1 & & & 0 & 63 \\
\hline & & \multirow{2}{*}{ Iyverdi: 319-323 } & Yenice Vardar & 20 & 17 & 3 & 3 & 4 & 7 & 7 & 2 & 3 & 7 & & & & 1 & & 1 & & & & 55 \\
\hline & & & Villages & 44 & 43 & 1 & & 1 & 1 & & & & & & & & & & & & & & 46 \\
\hline & & NOW & Giannitsa & 2 & 2 & 0 & & 1 & & & 2 & 2 & & 1 & & & & & & & & & 8 \\
\hline \multirow{5}{*}{32} & \multirow{5}{*}{ 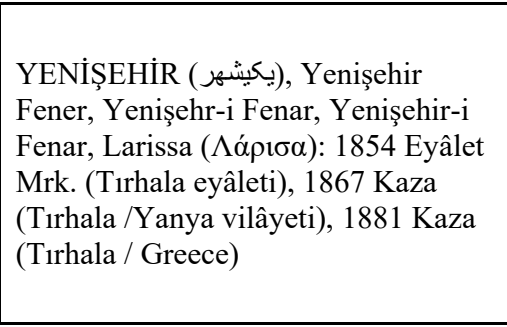 } & (Evliyâ 2011a: 190-2) & يكشير & 71 & 22 & 49 & $>1+3+3$ & 22 & 10 & & $21+1 \mathrm{~B}$ & 5 & & & 1 & & & & & & & & 138 \\
\hline & & Yanya Vilayet Salnâmesi 1294: 123-4 & يكيشه/قضشاء & 147 & & & 6 & 70 & 36 & & 69 & 4 & & & 20 & & & 63 & & & many & & 268 \\
\hline & & \multirow{2}{*}{ Iyverdi: 323-332 } & Yenişehir & 78 & 62 & 16 & 12 & 22 & 14 & 2 & 21 & 6 & 1 & 1 & 3 & & & & & & 2 & & 162 \\
\hline & & & Villages & 91 & 81 & 10 & 1 & 5 & 9 & 1 & 6 & 3 & 1 & & 1 & & & & & & & & 118 \\
\hline & & NOW & Larissa & 2 & 2 & 0 & & & & & $1 \mathrm{~B}$ & 1 & & & 1 & & & & & & 1 & & 6 \\
\hline \multirow{6}{*}{33} & \multirow{6}{*}{$\begin{array}{l}\text { ZiHNE (jيخذ), Zilhova, Zihna, Zihni, } \\
\text { Nea Zichni (NÉa Zíxvn):1867 Kaza } \\
\text { (Siroz / Selanik vilâyeti), 1913 Kaza } \\
\text { (Siroz / Greece) }\end{array}$} & (Evliyâ 2011a: 123) & زيخنه & 2 & 1 & 1 & 1 & 1 & 1 & & 2 & 1 & & & & & & & & & & & 8 \\
\hline & & Shemseddin 1311, IV: 2438 & زيخن//شضاء & 33 & 25 & 8 & 1 & 18 & 1 & & 20 & 3 & & & & & & & & & & & 76 \\
\hline & & Selanik Vilayeti Salnâmesi 1325: 396 & زيخن//قصبه & $>3$ & 3 & & 1 & 1 & 1 & & & & & & & & & & & & & & 6 \\
\hline & & Jurdi. $323-5$ & Zihne & 7 & 7 & 0 & 1 & 3 & 1 & & 2 & 1 & & & & & & & & & & & 15 \\
\hline & & lyverdı: 332-5 & Villages & 24 & 22 & 2 & 3 & 3 & 1 & & & & & & 1 & & & & & & & & 32 \\
\hline & & NOW & Nea Zichni & & & & & & & & & 1 & & & & & & & & & & & 1 \\
\hline
\end{tabular}




\begin{tabular}{|c|c|c|c|c|c|c|c|c|c|c|c|c|c|c|c|c|c|c|c|c|c|c|c|}
\hline & Place & 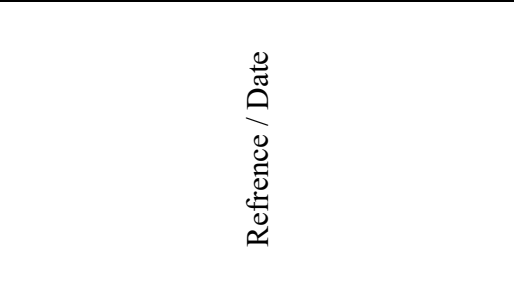 & 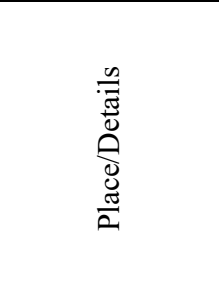 & 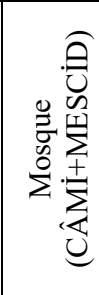 & 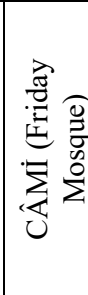 & 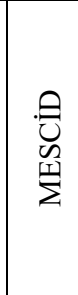 & 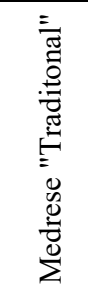 & $\frac{\frac{5}{s}}{\frac{s}{2}}$ & 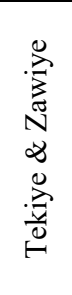 & 莺 & 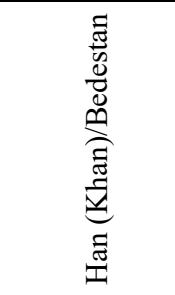 & 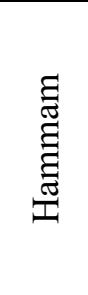 & 童 & $\frac{\breve{g}}{U}$ & 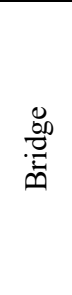 & $\begin{array}{l}\frac{0}{\bar{m}} \\
\stackrel{u}{u s}\end{array}$ & 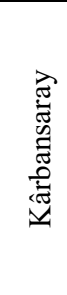 & 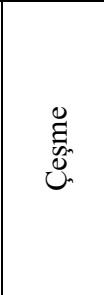 & $\begin{array}{l}\frac{\bar{z}}{\overline{\frac{z}{2}}} \\
\frac{\bar{E}}{4}\end{array}$ & $\begin{array}{l}\text { 言 } \\
\text { 吕 }\end{array}$ & 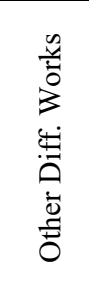 & 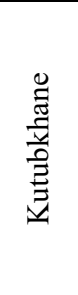 & 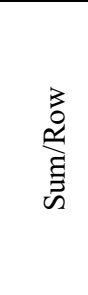 \\
\hline \multirow{5}{*}{34} & \multirow{5}{*}{ 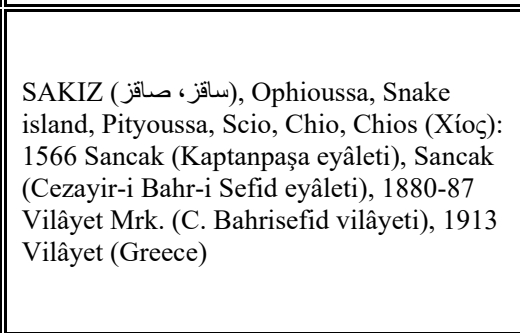 } & (Evliyâ 201 1b: 131-5) & سازز & 7 & 7 & & & & 2 & & 1 & 3 & & & & 1 & & 82 & & & & & 96 \\
\hline & & Shemseddin 1311, IV: 2486 & ساتز & 9 & 9 & & 2 & & 3 & & & & & & & & & & & & & & 14 \\
\hline & & Cezair Bahr-i Sefid Salnâmesi 1293: 145 & ستر & 8 & 5 & 3 & 2 & 1 & 2 & & 2 & 2 & & & & & & 9 & & & & & 26 \\
\hline & & Cezzair Bahr-i Sefid Salnâmesi 1312: 316-7 & سازي & 9 & & & 2 & 75 & 3 & 0 & 5 & 2 & & & & & & 33 & & & & & 120 \\
\hline & & Now & Chios & 3 & 3 & & & & & & & 2 & 1 & & & 1 & & 4 & & & 2 & & 13 \\
\hline \multirow{4}{*}{35} & \multirow{4}{*}{ 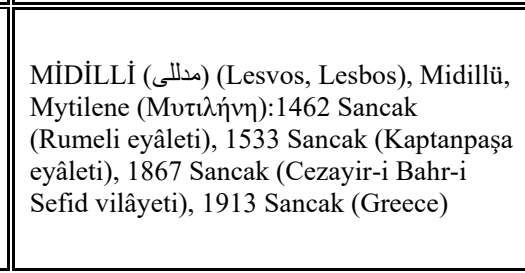 } & Shemseddin 1316, VI: 4234 & 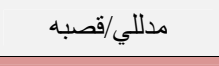 & 14 & 14 & & & & & & & & & & & & & & & & & & 14 \\
\hline & & Cezair Bahr- Sefid Salnâmesi 1293: 145 & مدللو & 24 & 23 & 1 & & 69 & 5 & & & 12 & 1 & & & & & 132 & & & & & 243 \\
\hline & & Cezzair Bahr-i Sefid Salnâmesi 1312: 316-7 & مدللو & 63 & & & 3 & 124 & 8 & & & 12 & 1 & & & & & 518 & & & & & 666 \\
\hline & & Now & Mytilene/Lesvos & 9 & 9 & & 2 & 1 & 1 & & & 3 & & & & 3 & & 225 & & & 4 & & 248 \\
\hline \multirow{5}{*}{36} & \multirow{5}{*}{ 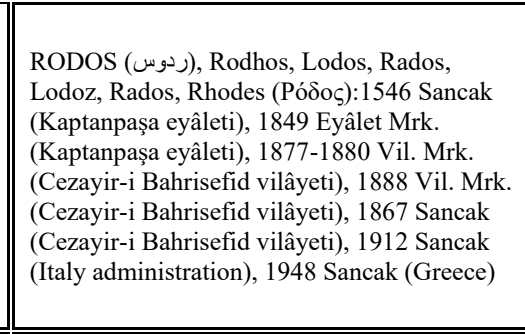 } & (Evliyâ 2011b: 257-275) & ردوس & 36 & 6 & 30 & $4+1$ & 17 & 4 & 1 & & 4 & & & & & & & & & & & 67 \\
\hline & & Shemseddin 1308, III: 2273 & ردوس & 44 & 44 & 0 & 3 & 26 & 4 & & 1 & 3 & & & & & & & & & & & 81 \\
\hline & & Cezair Bahr-i Sefid Salnâmesi 1293: 147 & ردوس & 37 & 13 & 24 & 3 & 7 & 3 & & & 3 & 5 & & & & & 25 & & & & & 83 \\
\hline & & Cezair Bahr-i Sefid Salnâmesi 1312: $316-7$ & ردوس & 54 & & & 6 & 65 & 5 & 1 & 3 & 6 & & & & & & 124 & & & & & 210 \\
\hline & & Now & Rhodes & 13 & 13 & & & & & 1 & & 2 & 13 & 1 & & & & 12 & & & 15 & 1 & 58 \\
\hline \multirow{3}{*}{37} & \multirow{3}{*}{ 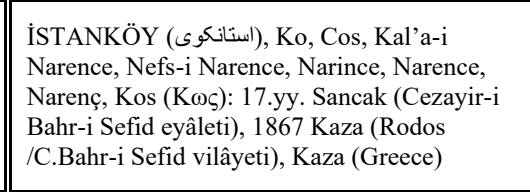 } & $\begin{array}{l}\text { (Evliyâ } 2011 \mathrm{~b}: 242) \\
\end{array}$ & استانكري & $\frac{25}{5}$ & 3 & 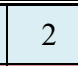 & & 7 & & & & 1 & & & & & & & & & & & 13 \\
\hline & & Cezair Bahr-i Sefid Salnâmesi 1293: 146 & استانكري & 13 & 8 & 5 & 1 & 35 & 1 & & & 3 & 3 & & & & & 29 & & & & & 85 \\
\hline & & Now & Kos & 6 & 6 & & & & & & & & 1 & & & 1 & & 2 & & & 3 & & 13 \\
\hline \multirow{2}{*}{38} & \multirow{2}{*}{ 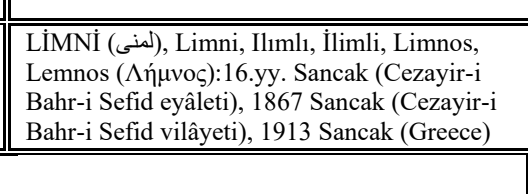 } & 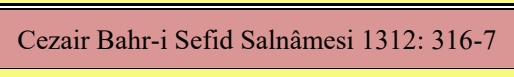 & لبيني & 18 & & & & 39 & 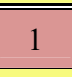 & 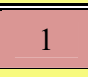 & 1 & 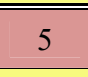 & & & & & & 369 & & & & & 416 \\
\hline & & Now & Lemnos & 1 & 1 & & & & 1 & & & & & & & 1 & & 1 & & & 1 & & 5 \\
\hline & & Evliyâ. Total & Greece & 1171 & 355 & 799 & 123 & 258 & 158 & 44 & $254+10$ Beds. & 156 & 0 & 1 & 22 & 9 & 10 & 2070 & 0 & 74 & 114 & 1 & 4458 \\
\hline & & \multirow{3}{*}{ Iverdi. Total } & Greece & 1245 & 944 & 250 & 143 & 277 & 238 & 57 & 135 & 99 & 26 & 5 & 18 & 16 & 9 & 4 & 6 & 2 & 112 & 0 & 2341 \\
\hline & & & Gr.Vvillages & 966 & 911 & 52 & 30 & 37 & 47 & 7 & 24 & 22 & 3 & 0 & 4 & 1 & 2 & 2 & 0 & 0 & 3 & 0 & 1145 \\
\hline & & & Total & 2211 & 1855 & 302 & 173 & 314 & 285 & 64 & 159 & 121 & 29 & 5 & 22 & 17 & 11 & 6 & 6 & 2 & 115 & 0 & 3486 \\
\hline & & NOW.Total & Greece & 145 & 142 & 3 & 10 & 6 & 24 & 7 & $2+3$ Beds. & 49 & 31 & 6 & 6 & 31 & 0 & 307 & 3 & 1 & 127 & 4 & 762 \\
\hline
\end{tabular}




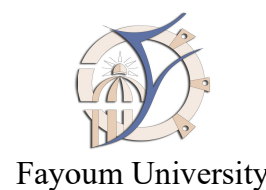

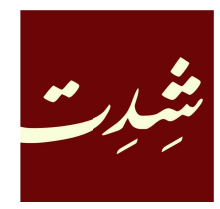

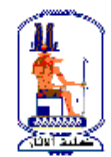

Faculty of Archaeology

\section{SOME CONSIDERATIONS ON THE TABLE'S DATA}

This inventory does not exhaustive in presenting the architectural heritage of the Ottoman period in Greece. It contributes to our understanding of specific aspects regarding ottoman buildings in Greece until the late $18^{\text {th }}$ and the beginning of the $19^{\text {th }}$ centuries. The numbers themselves are subject to different interpretations. In several cases, the mosques' count includes the churches which were converted into mosques. Some types of buildings such as fountains and bridges appear to be more numerous than those cited in the table. Moreover the buildings' categories included in our table only represent the so-called typical Ottoman architecture. However, several types of architectural heritage constructed under the Ottomans have not been included, such as townships, residential buildings, monasteries, churches, synagogues, hospitals, bazaars (çarşı or Souq in Arabic), shops (dukkan), industrial buildings and workshops, olive-press, windmills, watermills, cafes or coffee-shops (kahvehane), and some types of military and governmental buildings as well.

The picture of urbanisation at late Ottoman period in Greece is different due to the essential change in the nature and policy of Ottoman ruling at that time, especially after the Tanzimât in 1839. Several aspects of the latter period could be understood better thanks to the Ottoman salnames and the analysis of the relevant buildings, archives and historical texts. These indicate new types of buildings that were constructed in Greece such as non-Muslim educational buildings, railway stations, telegraph and post stations, banks, gümürk buildings, hospitals (hastane), pharmacies (eczane), factories, hotels, theateres (tiyatro), backery (firm).

Furthermore, during the late Ottoman period there was a clear Western influence on both traditional and newly designed buildings, not only in the architectural elements and decorations but also in the plans and functions. The typical Ottoman medrese was replaced by a new construction associated to a modern concept of education; it was innoviative not only in the architectural form but also in its scope, operating system, courses and tools as well. Several new Ottoman governmental buildings were constructed according to the central plan concept throughout Greece.

\section{QUANTATITIVE ANALYSING OF OTTOMAN BUILDINGS IN GREECE CONSIDERING THE FUNCTION AND THE REGION THEN AND NOW}

Often, the comparisons between the numbers of past and present Ottoman buildings in Greece and in the Balkans attempts to illustrate the voluntary destruction of the Ottoman architectural heritage ${ }^{33}$ However, this is not entirely accurate, as differs from one region to another and from one city to another. In fact, this quantitative approach in studies is a complex issue, since presenting and analysing the numbers of Ottoman buildings in Greece then and now could lead to different conclusions in light of the selected sample, buildings' type, period, and geographical region.

\footnotetext{
${ }^{33}$ The Cultural Imperialism of Greece and the Turkish-Islamic Works.
} 
Ottoman mosques in the Greek Thrace provide an obvious example. The number of existing historic mosques (with historical and architectural value) amounts to 31 , but the total number of the existing mosques is 235 while their number at the end of the Ottoman rule in Greece according to Iyverdi was 611 . Thus, dealing with numbers gives a very different percentage between the numbers then and now as follows: $31 \div 611=5 \%$, but $235 \div 611=38.5 \%$ which is a great disparate result. The same appears when comparing the number of all mosques in Greece then and now: $143 \div 2211=6.5 \%$, but 347 (143 historic mosques +204 in Thrace) $\div 2211=15.7 \%$. The latter percentage differs again to be $18.5 \%$ if the comparison is between the number of the Friday-mosques (cami) minus smallmosques (mescid): $344 \div 1855$. Moreover, this percentage will increase if the then number of mosques minus the churches which were converted into mosques with the prominent examples of the Theotokos Kosmosoteira Church or Gazi Süleyman Paşa Cami at Feres (Firecik) in Thrace, in addition to many examples in Thessaloniki, Rhodes and Crete. The change in the aforementioned percentage continues if the comparison is restricted to only one governorate in Thrace as Komotini (Gümülcine). The number of mosques in Komotini is 166 for the past and 131 for the present, showing that $79 \%$ have survived to present days. The same changes appear when calculating all the numbers of Ottoman buildings in Greece then and now.

In specific regions in Greece, such as Karditsa (Kardiça), Lamia (İzdin), Servia (Serfiçe), and Nea Zichni (Zihne) all the mosques that once stood have by now completely disappeared. Thus, in order to provide a global view of the preservation of Ottoman buildings in Greece, all the regions have to be taken into account, and if we don't it may sway the results.

\section{QUANTATITIVE ANALYSING CONSIDERING THE FUNCTION}

The first quantitative comparison of Ottoman buildings in Greece is between Evliyâ's time in the $17^{\text {th }}$ century and the end of the Ottoman rule considering the Iyverdi's work, Ottoman Salnames, and Kamûs-ül Â'lâm.

Regarding mosques - congregational mosques or Friday mosques (cami')- there is a remarkable increase in their numbers from Evliyâ's time to the early $20^{\text {th }}$ century (Chart 1). On the other hand, the number of small mosques (mescid) decreased significantly. In contrast, Friday mosques prominently increased, illustrating the wide-ranging conversion of mescids into Friday mosques after Evliyâ.

In fact, this phenomenon of converting mescids into Friday mosques is concomitant to the authorisation of having multiple Friday mosques in the same city (kasaba). Hartmuth suggests the late $15^{\text {th }}$ century $^{34}$ to date this phenomenon in the Balkans. Possibly, this dating is corroborated in the big centres (capitals) such as Thessaloniki. However, one Friday mosque remained sole for some later decades in some cities such as in Komotini ${ }^{35}$ and Veria (Karaferya); ${ }^{36}$ at least until 1528 , there was only one Friday mosque in these cities.

\footnotetext{
${ }^{34}$ Hartmuth, "A Late Fifteenth Century Change in the Rapport of Friday Mosque and Ottoman City? ... ."

${ }^{35}$ Bıçakçı, Yunanistan'da Türk mimari, pp. 129-130.

${ }^{36}$ Kiel and Gara, "KARAFERYE ... ," 392.
} 


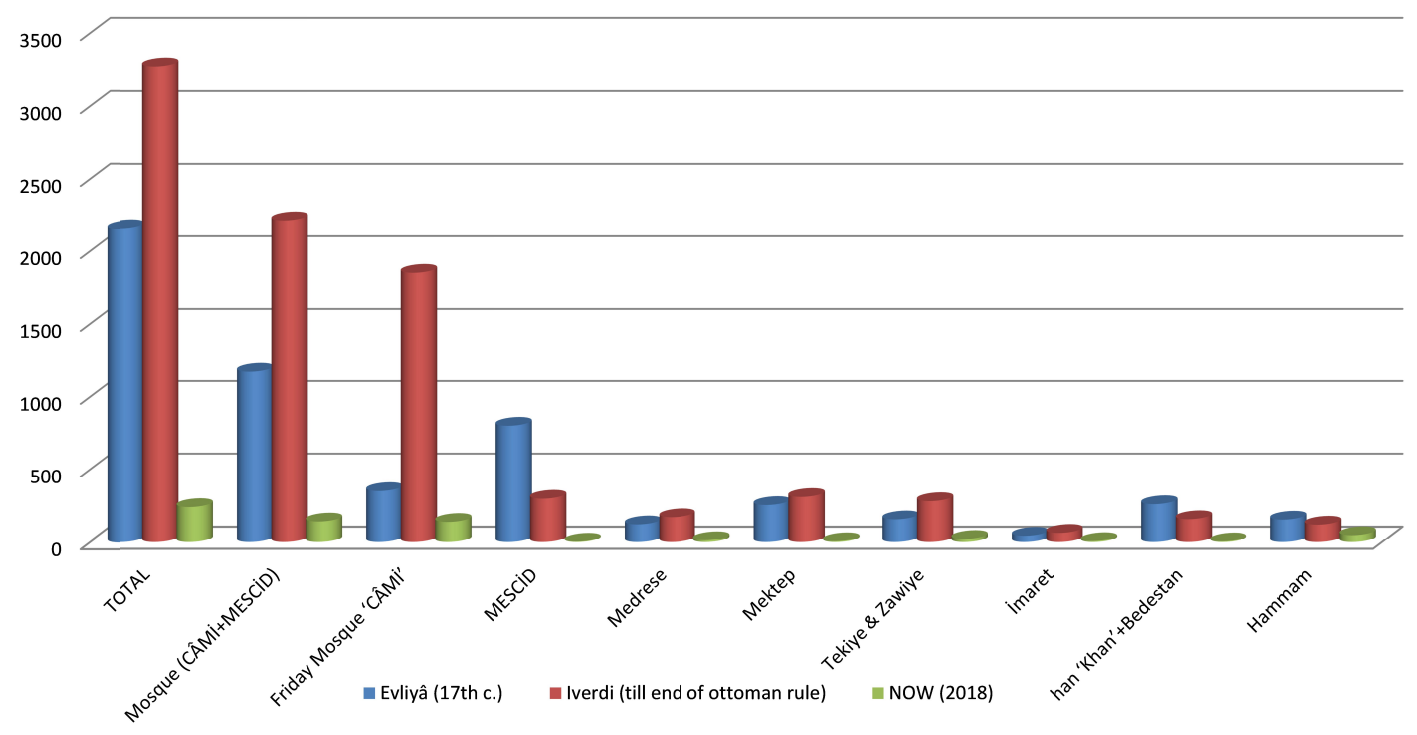

Chart 1. Proportions of typical Ottoman buildings in Greece then and now

Only three examples of mescids currently survive. No doubt that the absence of a minaret and the simple architecture of the mescids facilitated their reuse as dwellings or other functional buildings. Therefore, the comparison between the numbers of the Ottoman mosques in Greece then and now gives an entirely different perspective if it is restricted to the Friday mosques (Chart 1). Moreover, one must consider the number of mosques which were originally churches, as it strongly affects the aforementioned proportion.

With the exception of the mosques, Evliyâ's time shows a peak in constructing typical Ottoman architecture including medrese, mektep, tekiye, imaret, han, bedestan, and hammam (souq in Arabic or bath) (Chart 1). The increasing construction rates of medrese, mektep, tekiye, and imaret buildings between Evliyâ's time and the end of the Ottoman rule in Greece is very modest in proportion to this long period (Chart 1).

The numbers and types of Ottoman buildings in Greece reflect the nature of the Ottoman policy and the changes that took place over centuries. Most of the buildings served the community, regardless of religion, as they had social, economic, and health benefits, as for instance, the imaret and hammam structures dating to the first two or three centuries of the Ottoman rule (Chart 1).

The Ottoman hammam was not originally only constructed for economic purposes but to serve the local community with various social and health functions. Thus, sultans themselves built hammams during the early period of the Ottoman rule, and the Bey Hammam built by Murat II at Thessaloniki in 1444 is a distinguished example. Later, the concept was altered to become a building of a more commercial function.

The cost of constructing and operating the aforementioned buildings is very high and continuous, especially the imaret. This observation, also applies to the medrese and the mektep buildings in comparison to mosques as typical religious buildings (cami and mescid). This may explain the remarkable increase of the latter versus the modest growth rate in the numbers of the imaret, medrese, and mektep buildings after Evliyâ.

The change in the numbers of buildings according to their function summarizes the alteration in nature of the Ottoman policy over the centuries. From the early period until 
Evliyâ's time, the Ottomans adopted a foundation policy, spending money collected from booty and taxes on the local community and human development. This policy sent one clear message: the Ottomans came to these regions to establish their own world forever. Thus, they did their best to get the local Greek citizens on their side. The aforementioned welfare buildings, especially the imaret $^{37}$, were one of the tools to achieve their goals.

The stability of the Ottoman rule in these regions and the various historical indications of the local people's preference for the Ottomans rather than previous rulers, especially the Venetians, show to what extent the Ottoman policies were effective.

This policy of the first generations (paşas and beğs) of Ottomans was changed during the $18^{\text {th }}$ century as the numbers of the buildings after Evliyâ suggest (Chart 1). Instead of spending the collected money on the local community, the late Ottoman governors collected money for themselves and spent it on their needs. The context that produced this change in the Ottoman policy was one of the reasons of the Greek revolution against them.

Another factor explains the limited increase in these categories of buildings: they characterised the capitals of sancaks and main cities (kaza), referring to creating new Ottoman "Islamic" cultural centers. These locations were covered by such buildings until Evliyâ's time. But the systematic increase of the population after Evliyâ refutes this argument as shown in various written sources. ${ }^{38}$

One may suggest another reason for the decrease in numbers of typical Ottoman commercial buildings hans, bedestans and hammams by the end of the Ottoman rule versus Evliyâ's time (Chart 1). This decrease is explained by a lack of demand for such buildings, due to changes during the late period of Ottoman rule in Greece, especially following the industrial revolution, free trade and movement, and the availability of water inside houses. This led owners of some of these buildings to modify their function, or replace them with new structures. Thus, by the end of the Ottoman rule they have decreased in number, compared to Evliyâ's time.

Statistics show the quantitative differences of varying types of buildings considering the disparity in the numbers between the regions, cities and the villages. They declare that, the amount of typical Ottoman buildings, excluding the mosques, in the villages was limited.

Charts 1 and 2 examined typical ottoman structures excluding the fountains (çeşme) and the other different works showed in the table. In several times these buildings are not counted, and the sources only state that they are some or many. Regarding the fountains (çeşme), there are three hundred and seven extant ones in Greece; the highest number among the existing Ottoman buildings with special reference to Mytilene (Midilli) and Crete (Girid). Despite this high number, it remains small compared to the past.

\footnotetext{
${ }^{37}$ For more information on the exceptional role of the imarets in the community, its operation, beneficiaries, and impact on the local people and the European travellers as well, see: Lowry, "The 'Soup Muslims' of the Ottoman Balkans ...," pp. 106-111.

${ }^{38}$ There is a large body of written sources, all in Ottoman, on the size of the population of the Greek regions, including the census and taxation survey, the Muhasebe Defters, the Mufassal Tahrirs, and the Salnâmes. These resources sketch the rough outlines of the demographic history of these regions. For instance Kiel published the growth of the population of the Island of Mytilene/Midilli during the ottoman period (1488-1900) considering these resources. See:

Kiel, "The Medrese and Imaret of Hayreddin Barbarossa ...," p. 167.
} 


\section{QUANTATITIVE ANALYSING CONSIDERING THE REGION}

Chart 2 follows the changes in numbers of Ottoman buildings in Greece during three different periods with geographical index. The growth in the numbers of Ottoman buildings in Central Greece (Atika-Biyotiye), Peloponnese (Mora) and Thessaly (Tesalya) was limited after Evliyâ. On the other hand, the proliferation rate in Epirus, Crete, Aegean Islands (Cezayir-i Bahr-i Sefid), Thrace, and Macedonia after Evliyâ until late Ottoman ruling is remarkable. This was partially due to the liberation of Central Greece, Peloponnese and Thessaly being earlier than those of other regions, as well as their early revolutionary wars against the Ottomans. This also explains the limited number of existing Ottoman buildings in Central Greece, Peloponnese and Thessaly.

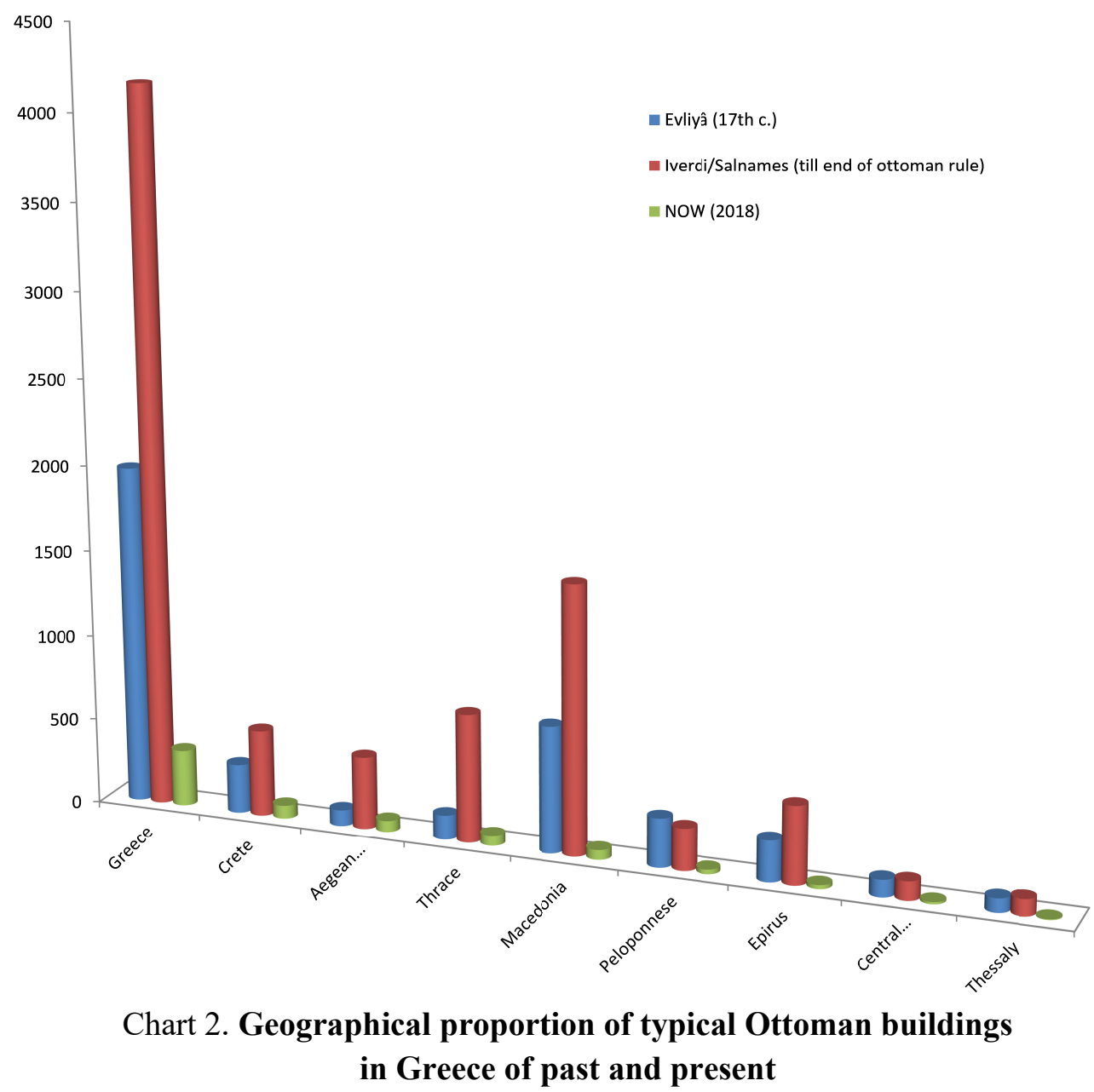

The largest amount of surviving Ottoman architectural heritage in Greece, considering the çeşme and other different works -included in the table-, is found in the Aegean Islands, Crete, Macedonia, and Thrace in descending order. But with the addition of two hundred non-historic mosques -i.e. those have no value in terms of the history of art and architecture- in Thrace, the order changes to Thrace having the largest surviving number. Thus, the regions that still have Muslim minorities in Greece and those located near present-day Turkey have the highest numbers of existing Ottoman buildings. Neighbourly 
relationships and consequent economic relations played a role in preserving the Ottoman architectural heritage in these regions. There is an inverse geographical relationship between the cultural aversion against 'Turkish' objects and the number of existing Ottoman buildings. This number is decreased from East to West.

The city of Ioannina (Yanya) is an exception in Epirus, north-western Greece, with an impressive and perfectly preserved existing Ottoman architectural heritage. This clearly reflects Ioannina's own historical contexts, which differ from other Greek regions either during the Ottoman period or after the incorporation into the Greek State in 1913.

\section{THE FACTORS BEYOND THE DEMOLITION OF OTTOMAN ARCHITECTURAL HERITAGE IN GREECE}

Comparing the number of typical Ottoman buildings in Greece then and now gives the ratio $13.7 \%(448 \div 3273)$. This shows to what extent the Ottoman architectural heritage in Greece suffered, but remains one of the largest preserved Ottoman architecture in the Balkans.

The reasons behind the destruction of a large proportion of Ottoman buildings in Greece were due to revolutionary revenge, to political motives, or to a local aversion against the 'Turkish' objects, but there are other causes that have often been dismissed. Wars, earthquakes, explosions, and reuse of the buildings by other conquerors or according to the new needs of the Greek-Christian community in some regions following the new demographic situation after the treaty of Lausanne in 1923, also reduced the numbers of existing Ottoman buildings.

Some Ottoman buildings were destructed or burnt during wars, mainly the Balkan Wars and the First World War, especially in Northern Greece. The Parthenon Mosque was demolished due to a huge explosion of the mortars bullets and explosive materials stored inside the Parthenon. ${ }^{39}$

Among the natural factors, earthquakes form the most real cause of the ruin of Ottoman buildings, even under the Ottomans themselves, with special reference to the 1856 Crete $^{40}$ earthquake. The impact of earthquakes on architecture is still perceived, as the Defterdar İbrahim Efendi Mosque in the Island of Kos (İstanköy) was damaged on 21 July 2017. It was a devastating 6.3 magnitude earthquake in the Aegean Sea, affecting seriously the Defterdar Mosque (1724) and its minaret was completely demolished. ${ }^{41}$

Though all these human and natural factors decreased the number of Ottoman buildings in Greece, the preserved Ottoman architectural heritage in Greece is still one of the largest in the Balkans area, displaying an amazing variety in function, plan, patrons, inscriptions, architects, originality, geographical distribution, and building techniques.

The existing Ottoman buildings in Greece are an international wealth that forms a significant part of the world tangible heritage. It still needs more studies and preservation projects. Preserving and reusing these buildings and the surrounding areas will certainly attract more touristic and economic investments.

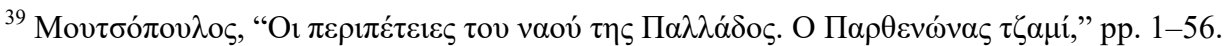

${ }^{40}$ Adiyeke and Adiyeke, "1856 Girit Depremi”.

${ }^{41}$ On the impacts of this earthquake on the Defterdar İbrahim Efendi Mosque in Kos and its state before and

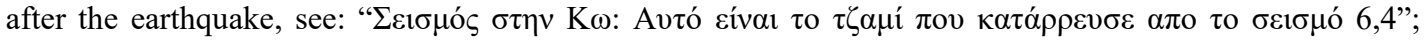

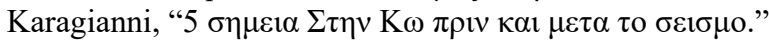




\section{REFRENCES}

- Adiyeke (A. Nükhet) and Adiyeke (Nuri), "1856 Girit Depremi”, Tarih Araştırmaları Dergisi, C.31, S.51, ss.1-38. Link: http://dergiler.ankara.edu.tr/dergiler/18/1687/17980.pdf [Access Date: June 7, 2018].

- Ak (Mahmut), Aşık Mehmed Menazırü'l-Avalim, 3 Vols. (Ankara 2007).

- Ameen (Ahmed), Islamic Architecture in Greece: Mosques. Foreword: Mostafa El Feki (Alexandria: Bibliotheca Alexandrina, 2017).

- Ayverdi (Ekrem Hakk1), Avrupa'da Osmanli Mimari Eserleri, IV. Bulgaristan, Yunanistan, Arnavutluk (Istanbul: Fetih Cemiyeti Yayınları 1982).

- Balducci (Hermes), Architettura Turca in Rodi (Milano: Editore Ulrico Hoepli, 1932).

- Balta (Evangelia), Les vakifs des Serrès et de sa région ( $X V^{e}$ et $X V I^{e}$ s.) (Athènes: Fondation Nationale pour la Recherche Scientifique 1995).

- Balta (Evangelia), Ottoman Studies and Archives in Greece, Analecta Isisiana LXX (Istanbul: Isis Press, 2003).

- Barkan (Ömer Lutfi), "İmaret sitelerinin Kuruluş ve isleyişi." Iktisat FaKültesi Mecmuasi 23 (1963), pp. 239-378.

- Bıçakçı (İsmail), Yunanistan'da Türk mimari eserleri, önsöz Ekmeleddin İhsanoğlu (İstanbul: Ircica, 2003).

- Çam (Nusret), Yunanistan'Daki Türk Eserleri (Ankara: Türk Tarih Kurumu Basımevi, 2000).

- Duman (Hasan), Osmanl yıllıkları (Salnameler ve Nevsaller) (Istanbul: Ircica 1982).

- Eren (Halit), Oğuz (Mustafa) and Mete (Zekai), Balkanlar'da Osmanlı vakıflarl, vakfiyeler Yunanistan, 5 vols. (İstanbul : IRCICA, 2017).

- Evliyâ \#1: Evliyâ Çelebi, Seyahatname, Autograph manuscript, Bağdat köşkü 308, Book 8.

- Evliyâ \#2: Evliyâ Çelebi, Seyahatnâmesi .vol. 8 (İstanbul :Orhaniye Matbaasi, 1928).

- Evliyâ \#3: Evliyâ Çelebi (bin Derviş Mehemmed Zilli), Evliyâ Çelebi Seyahatnamesi VIII. Kitap, [Topkapı Sarayı Kutuphanesi Bağdat 308 numaralı yazmanın transkripsiyonu-dizini], edited by Kahraman (Seyit Ali), Dağlı (Yücel) and Dankoff (Robert), (İstanbul: Yapı Kredi Yayınları, 2003).

- Evliyâ \#4: Günümüz Türkçesiyle Evliya Çelebi Seyahatnamesi 5. Kitap 2 Cilt Akkirman Belgrad - Gelibolu - Manastır - Özü - Saraybosna - Slovenya - Tokat - Üsküp, 5. kitap, 2. Cilt, haz. Kahraman (Seyit Ali), (İstanbul: Yapı Kredi, 2010).

- Evliyâ \#5: Günümüz Türkçesiyle Evliyâ Çelebi seyahatnâmesi: Gümülcine, Kavala, Selânik, Tirhala, Atina, Mora, Navarin, Girit Adasl, Hanya, Kandiye, Elbasan, Ohri, Tekirdağı, 8. kitap, 2 Cilt, haz. Kahraman (Seyit Ali), (İstanbul: Yapı Kredi, 2011).

- Evliyâ \#6: Günümüz Türkçesiyle Evliyâ Çelebi seyahatnâmesi: Kütahya, Manisa, İzmir, Antalya, Karaman, Adana, Halep, Şam, Kudüs, Mekke, Medine, 9. kitap, 2. Cilt, haz. Kahraman (Seyit Ali), (İstanbul: Yapı Kredi, 2011).

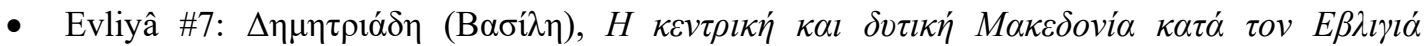

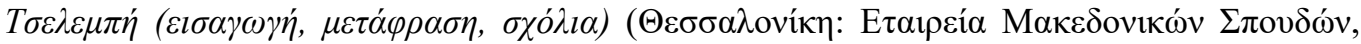
1973).

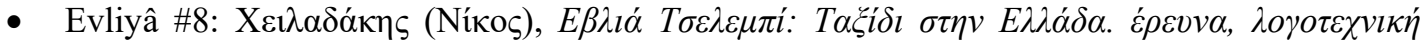
$\alpha \pi \delta ́ \delta o \sigma \eta(\mathrm{A} \theta \dot{v} v \alpha, 1991)$.

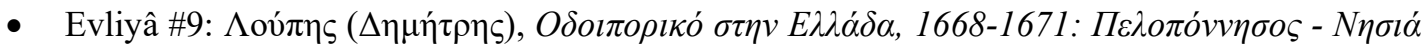

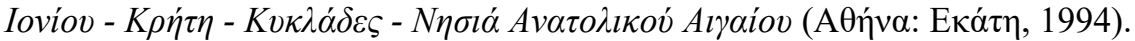

- Eyice (Semavi), "Yunanistan'da Türk mimari eserleri." Türkiyat Mecmuasi 11 (1954), pp. 157-182.

- Eyice (Semavi), “Yunanistan'da Türk mimari eserleri." Türkiyat Mecmuasi 12 (1955), pp. 205-230. 
- Giapitsoglou (Konstantinos), "Veli Pasha Complex. Tekes - Mosque - Medrese - Imâret," in Ottoman Architecture in Greece, pp. 442-443.

- Gökbilgin (Tayyip), Edirne ve Paşa Livâsı (İstanbul: İstanbul Üniversitesi Edebiyat Fakültesi 1952).

- Hartmuth (Maximilian), "A Late Fifteenth Century Change in the Rapport of Friday Mosque and Ottoman City? A Case Study Of Macedonia" in: Centre and Periphery? Islamic Architecture in Ottoman Macedonia, 1383-1520 (FWF P26406, 2014-2017), 1-19. Link: https://www.academia.edu/34115981 [Access Date: Jan. 7, 2018]

- Kiel (Machiel), "The Oldest Monuments of Ottoman-Turkish Architecture in the Balkans: The Imâret and the Mosque of Ghazi, Evrenos Bey in Giimiilcine (Komotini) and the Evrenos Bey Khan in the Village of Ilica Loutra in Greek Thrace (1370-1390)." Sanat Tarihi YilliğgKunsthistorische Forschungen 12 (Istanbul 1983), pp. 117-144.

- Kiel (Machiel), Studies on the Ottoman Architecture of the Balkans (London: Variorum, 1990).

- Kiel (Machiel) and Gara (Eleni), “KARAFERYE. Yunan Makedonyası'nın güneyinde bugünkü adı Béroia (Véria) olan şehir," TDV İslâm Ansiklopedisi'nin 24 (2001), 392.

- Kiel (Machiel), "The Quatrefoil Plan in Ottoman Architecture Reconsidered in Light of the "Fethiye Mosque" of Athens". Muqarnas 19 (2002), pp. 109-122.

- Kiel (Machiel), "The Medrese and Imaret of Hayreddin Barbarossa on the Island of Lesbos/Midilli: A little-known aspect of the cultural history of Sappho's Island under the Ottomans (1462-1912)," SHEDET (Annual Peer-Reviewed Journal Issued By The Faculty Of Archaeology, Fayoum University), 5 (2018), pp. 162-176.

- Konuk (Neval), Ottoman Architecture in Lesvos, Rhodes, Chios and Kos Islands (Ankara, The Center for Strategic Research, 2008).

- Konuk (Neval), Ottoman Architecture in Greece I(Ankara, The Center for Strategic Research, 2010).

- Lowry (Heath), Studies in Defterology: Ottoman Society in the Fifteenth and Fifteenth Centuries (Istanbul: ISIS, 1992).

- Lowry (Heath), The Nature of the Early Ottoman State (Albany: State University of New York Press, 2003).

- Lowry (Heath), The Shaping of the Ottoman Balkans 1350-1550: The Conquest, Settlement and Infrastructural Development of Northern Greece (Istanbul: Bahçeşehir University Publications, 2008).

- Lowry (Heath), Ottoman Architecture in Greece: A Review Article with Addendum and Corrigendum (Istanbul: Bahçeşehir University Press, 2009).

- Lowry (Heath), “The 'Soup Muslims' of the Ottoman Balkans: Was There A 'Western' and 'Eastern' Ottoman Empire?", In D. Quataert and B. Tezcan (eds.): Beyond Dominant Paradigms in Ottoman and Middle Eastern/North African Studies: A Tribute to Rif'at AbouEl-Haj (İstanbul: İSAM, 2010).

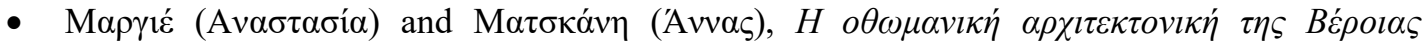

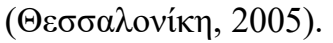

- Ottoman Architecture in Greece, Brouskari, E. (ed.), Athens: Hellenic Ministry of Culture, Directorate of Byzantine; Post-Byzantine Antiquities, 2008.

- Özergin (M. Kemal), "Eski bir rûznâmeye göre İstanbul ve Rumeli Medreseleri," Tarih Enstitüsü Dergisi vol. (4-5), 1973-1974, pp. 263-290.

- Papadopoulou (Varvara), "Aslan Pasha Medrese," in Ottoman Architecture in Greece, pp. 163-164.

- Sarıcaoğlu (Fikret), “KITÂAB-ı BAHRIYYE Pîrî Reis'in (ö. 962/1554) Ege ve Akdeniz kıyılarını tasvir eden coğrafî eseri." TDV İslâm Ansiklopedisi, cilt 26 (2002), pp. 72-75.

- Sezen (Tahir), Osmanli Yer Adlari (Alfabetik Sırayla) (Ankara: T.C. Başbakanlık Devlet arşivleri genel müdürlüğü, 2006).

- Stavrianos (Leften Stavros), The Balkans since 1453 (New York: Rinehart, 1958). 
- Şemseddin (Sami Frashëri), Kamûs-ül Â'lâm. Tarih ve cografya lûgati ve tabir-i esahhiyle kâffe-yi esma-yi hassa-yi camidir (Istanbul: Mihran 1889-1898), 6 vols.

- The Cultural Imperialism of Greece and the Turkish-Islamic Works (Ankara: Union of Western Thracians, 1986).

- Türkmen (Zekeriya), "Girit Adasini Osmanli İdaresinden Ayirma Çabalari: Yunan İsyanini Takip Eden Dönemdeki Gelişmeler (1821-1869)," Osmanlı Tarihi Araştırma ve Uygulama Merkezi Dergisi OTAM Vol. 12, Issue 12 (Jan 2001).

- VAKIFLAR GENEL MÜDÜRLÜĞ̈̈ ARŞSiVI (=VGMA), Defter nr. 623, s. 199, 193, sira 193.

- VAKIFLAR GENEL MÜDÜRLÜĞ̈ ARŞiVI (=VGMA), Defter nr. 734, s. 26-29, sira 10.

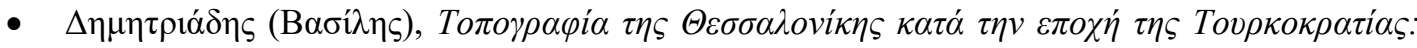

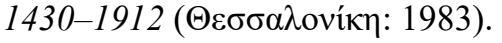

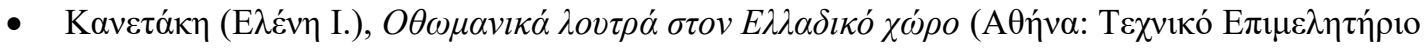
$\mathrm{E} \lambda \lambda \alpha \dot{\alpha} \alpha \varsigma, 2004)$.

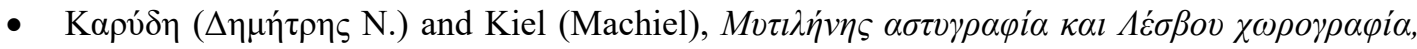

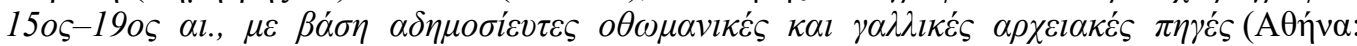
Oגкós, 2000.

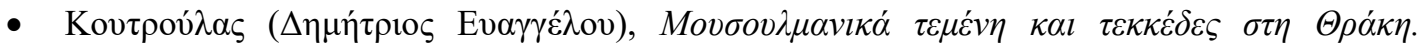

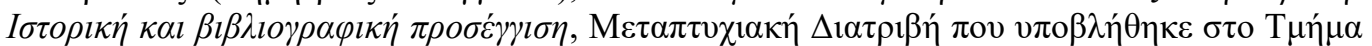

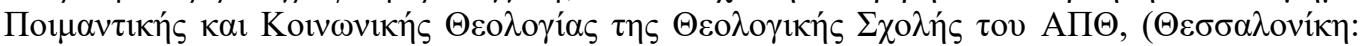
2009).

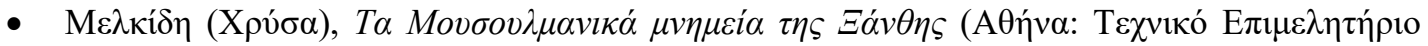

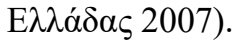

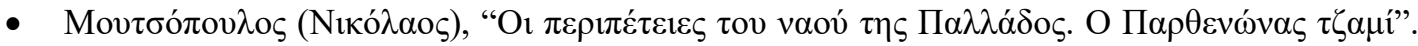

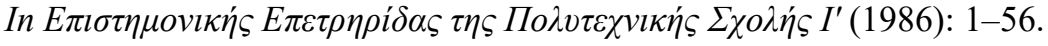

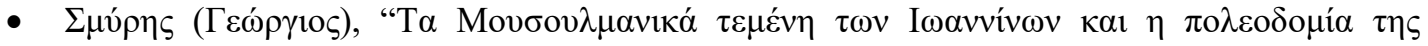

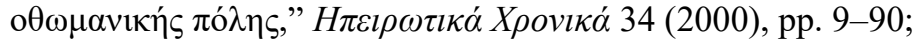

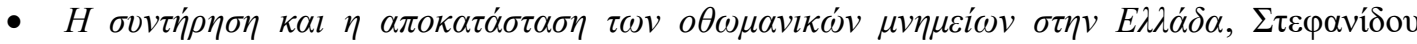

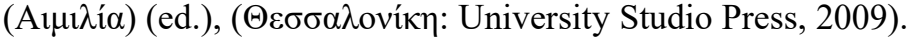

\section{Websites}

- http://digitalcrete.ims.forth.gr/index.php?1=1 [Access Date: April 1, 2016] 